\title{
Pilot Study to Evaluate the Practicality of Aquatic Ecosystem Monitoring \\ in Small Agricultural Streams in Alberta
}


Digitized by the Internet Archive in 2015

https://archive.org/details/pilotstudytoeval00ande 


\title{
Pilot Study to Evaluate the Practicality of Aquatic Ecosystem Monitoring in Small Agricultural Streams in Alberta
}

\author{
Prepared by: \\ A.-M. Anderson, R. Casey, J. Willis, and S. Manchur \\ Environmental Assurance \\ Alberta Environment
}

March 2009 
ISBN: 978-0-7785-8106-2 (Printed Edition)

ISBN: 978-0-7785-8107-9 (On-Line Edition)

Web Site: http://environment.gov.ab.ca/info/home.asp

Any comments, questions, or suggestions regarding the content of this document may be directed to:

Water Policy Branch Alberta Environment 7th Floor, Oxbridge Place 9820 - 106th Street

Edmonton, Alberta T5K 2J6

Phone: (780) 427-2654

Fax: (780) 422-6712

Additional copies of this document may be obtained by contacting:

Information Centre

Alberta Environment

Main Floor, Oxbridge Place

$9820-106^{\text {th }}$ Street

Edmonton, Alberta T5K 2J6

Phone: (780) 427-2700

Fax: (780) 422-4086

Email: env.infocent@gov.ab.ca 


\section{EXECUTIVE SUMMARY}

Monitoring, evaluation and reporting on aquatic ecosystem health are implicit requirements of the government of Alberta Water for Life commitment to assure "healthy aquatic ecosystems" (HAE). In addition to water quality monitoring, an increasing amount of monitoring of sediment quality and biological communities has occurred in recent years on major rivers, but comparable monitoring efforts on small streams have been very limited.

A pilot study was conducted on three streams from an existing water quality network of agricultural streams (i.e., the Alberta Environmentally Sustainable Agriculture or AESA network) to evaluate the feasibility and practicality of including sediment and non-fish biota monitoring. In fall 2006 AESA sampling locations on Rose Creek, the Blindman River and Strawberry Creek were sampled for benthic invertebrates (kick nets), epilithic and planktonic algae (community analysis and chlorophyll-a) and bottom sediments (nutrients and particle size) Field measurements and observations were taken of basic water quality parameters, hydrometric features, and reach, stream and bank characteristics.

The three watersheds are located in different, although adjacent ecoregions, and they are farmed with a different level of intensity. The Rose Creek site is more erosional in nature, and has lower dissolved nutrient levels and higher flows than the Blindman River and especially Strawberry Creek. Riparian damage due to cattle access was particularly evident at the Blindman River site.

Sampling of biological communities and sediments from small streams proved to be feasible and practical. However, sampling techniques and the type of field information differ significantly from those routinely obtained from larger provincial rivers. Therefore it would be important to invest in staff training if stream sampling was to be carried out routinely.

Benthic invertebrate and epilithic algal communities comprised many taxonomic groups for which ecological requirements and responses to various forms of disturbance are fairly well understood. The distribution of such organisms has been used elsewhere to develop indicators which in turn have been used to assess the 'health' or 'integrity' of aquatic ecosystems. Even at the scale of this pilot study it was possible to note differences in biological communities among streams that were linked to the degree of eutrophication (e.g., nutrient levels and dissolved oxygen conditions), and physical habitat characteristics and disturbance. Phytoplankton communities were not very diverse and appeared to have less potential for future monitoring programs.

One of the difficulties in assessing aquatic ecosystem health in Alberta lies in defining 'healthy' aquatic ecosystems. One approach is to use 'natural or least impacted' conditions, to define 'background' or 'reference conditions' and use these as a depiction of healthy conditions, for a given eco-region. To capture variability within an ecoregion, 
researchers advocate sampling about 20 carefully selected sites for 2 to 3 years. Applied to Alberta, 80 streams would have to be sampled to cover the four main ecoregions with agricultural activity. The effort is substantial, but would allow the description of expectations of 'healthy' conditions, which in turn would enable the definition of biocriteria. Such information is basic to health assessments of agricultural streams and similar streams influenced by other types of human activities (e.g., forestry, mining, urban development). 


\section{TABLE OF CONTENTS}

EXECUTIVE SUMMARY II

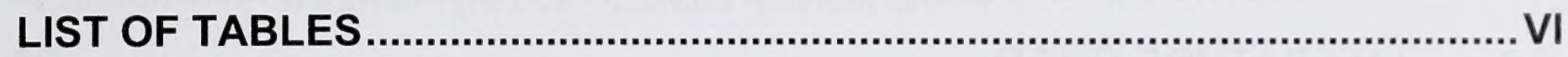

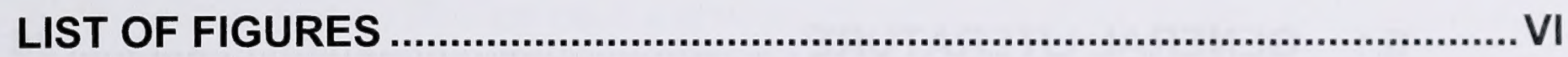

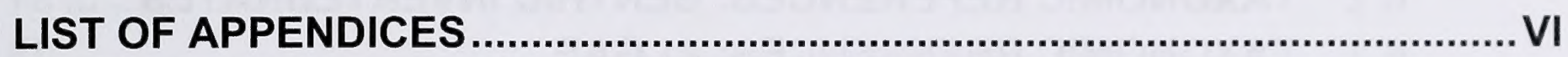

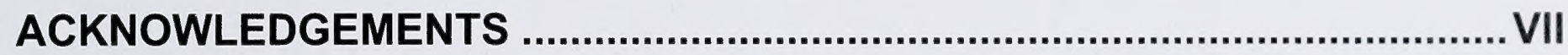

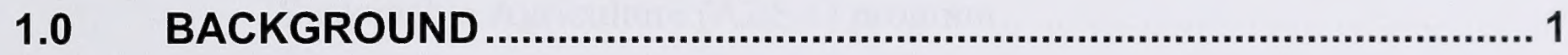

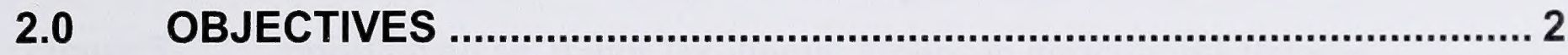

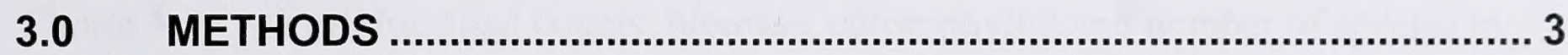

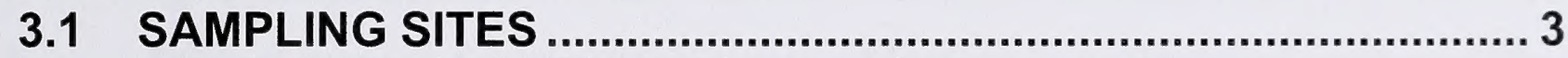

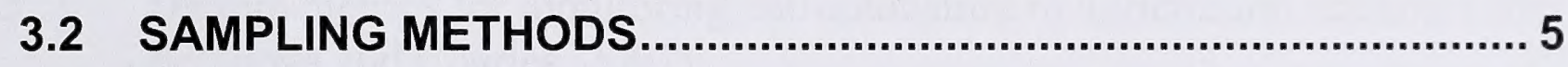

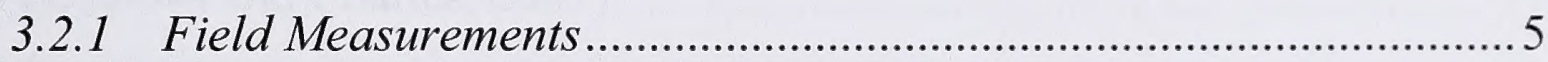

3.2.2 Benthic Invertebrates ........................................................... 5

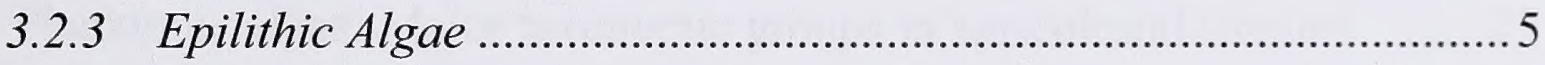

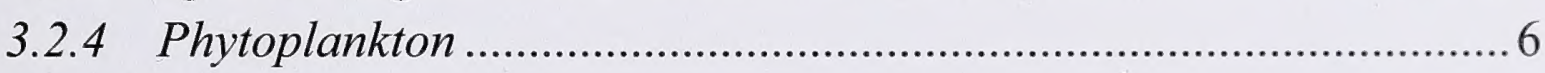

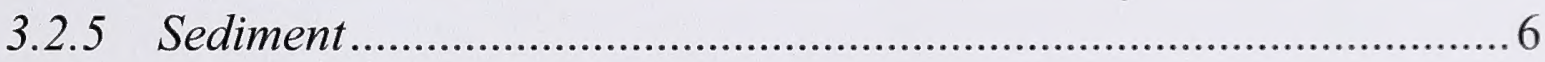

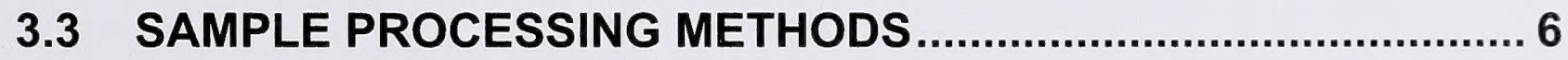

3.3.1 Benthic Invertebrate Samples ..................................................... 6

3.3.2 Epilithic and Plankton Algal Taxonomy, and Chlorophyll-a

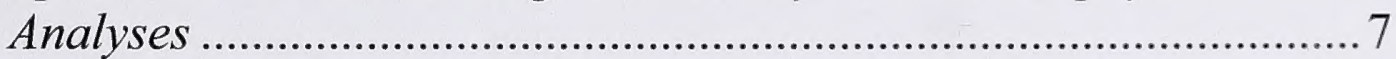

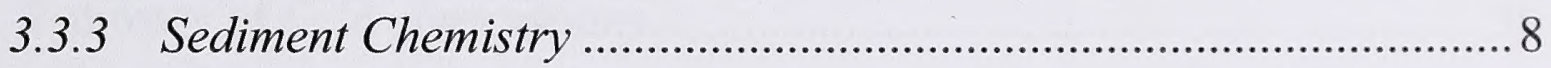

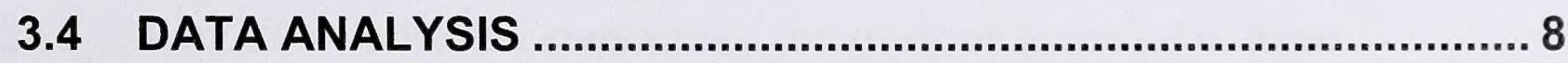

4.0 RESULTS AND DISCUSSION ........................................................ 10

4.1 GENERAL SITE DESCRIPTION ............................................. 10

4.2 PRACTICAL CONSIDERATIONS ABOUT THE PILOT

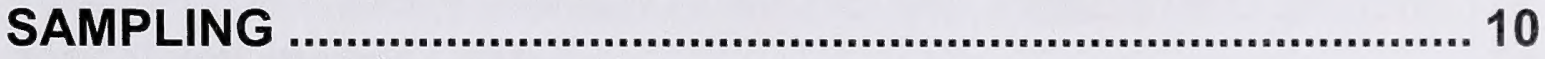

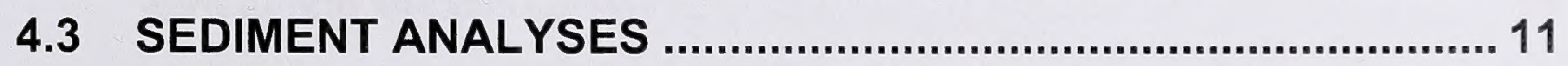

4.4 BENTHIC INVERTEBRATES .............................................. 12

4.5 EPILITHIC ALGAE................................................................. 16

4.6 PHYTOPLANKTON ................................................................. 21

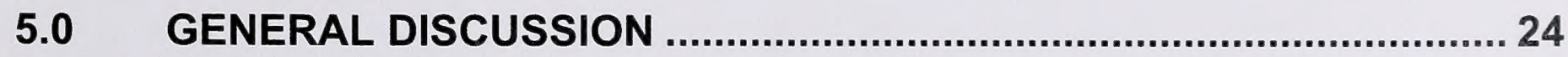

Pilot Study to Evaluate the Practicality of Biological Monitoring of Small Agricultural Streams iv in Alberta 


\subsection{SUITABILITY AND PRACTICALITY OF MONITORING}

TECHNIQUES .......................................................................... 24

5.2 SELECTION OF POTENTIAL INDICATORS OF HEALTH .......... 24

5.3 CONSIDERATIONS FOR FUTURE AEH MONITORING OF AGRICULTURAL STREAMS .................................................. 25

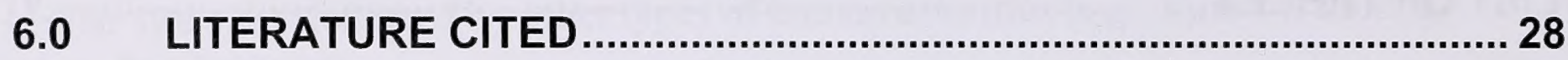

6.1 GENERAL LITERATURE .................................................. 28

6.2 TAXONOMIC REFERENCES: BENTHIC INVERTEBRATES ...... 31

6.3 TAXONOMIC REFERENCES: ALGAE .................................. 35 


\section{LIST OF TABLES}

Table 1 Summary of background information on the three AESA streams selected for the pilot study ....................................................................... 3

Table 2 Sediment particle size and nutrient levels............................................ 12

\section{LIST OF FIGURES}

Figure 1 Agricultural watersheds monitored under the Alberta Environmentally Sustainable Agriculture (AESA) program .................................................. 4

Figure 2 Benthic invertebrate data for three agricultural streams ......................... 14

Figure 3 Epilithic algae: major taxonomic groups in agricultural streams ............. 17

Figure 4 Epilithic algal counts, biomass, chlorophyll-a and number of species in

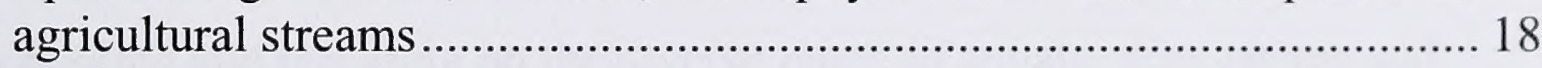

Figure 5 Diatom metrics for monitoring eutrophication in agricultural streams (after Potapova and Charles, 2007) ............................................................... 20

Figure 6 Planktonic algal counts, biomass, chlorophyll-a, and number of species. 22

Figure 7 Planktonic algae: Major taxonomic groups in agricultural streams 23

\section{LIST OF APPENDICES}

Appendix 1 Summary of field observations

Appendix 2 Benthic invertebrate community composition recorded in three agricultural streams in 2006.

Appendix 3 Benthic invertebrate community composition recorded in three agricultural streams in 2006 ...

Appendix 4 Phytoplankton density (number of units/L) and biomass (milligram $/ \mathrm{m} 3$ ) in agricultural streams (2006) 


\section{ACKNOWLEDGEMENTS}

Water for Life, Aquatic Ecosystem Health working group provided funding to process sediment and biological samples.

Epilithic chlorophyll- $a$ and sediment chemistry samples were analyzed at the Analytical Chemistry Laboratory of the Alberta Research Council in Vegreville under supervision of Frank Skinner. Dr. Michael Agbeti (Bio-Limno Research \& Consulting Inc.) Halifax, Nova Scotia identified and enumerated epilithic algae. William J. Anderson, Spruce Grove, Alberta sorted, identified and enumerated benthic invertebrates.

Mary Raven finalized figures and tables and formatted the report.

T. Hebben and R. Zurawell (Alberta Environment) provided valuable comments on the algal monitoring and L.R. Noton (Alberta Environment) reviewed the report. 


\subsection{BACKGROUND}

Monitoring, evaluation and reporting on aquatic ecosystem health are required to assure the Government of Alberta Water for Life (WFL) commitment of "healthy aquatic ecosystems." Healthy aquatic ecosystems (HAE) can be defined as functioning and diverse systems of biological communities (primary producers, invertebrates and vertebrates) interacting with an adequate chemical (water and sediment quality) and physical environment (hydrology, channel processes, riparian zones) (e.g., Whitford 2005).

In Alberta, provincial-scale monitoring of aquatic ecosystem health (AEH) has focused primarily on surface water quality of rivers and lakes. Expansion of provincial networks and programs to include sediment quality and non-fish biota (e.g., benthic invertebrates, and other aquatic biota) of rivers, streams, lakes and wetlands is required to support WFL goals. The development of such monitoring programs requires selection of practical and efficacious sampling methods, sample processing and data management procedures, and appropriate indicators of aquatic ecosystem health.

Monitoring, evaluating and reporting on the diverse range of aquatic ecosystems and human influences on a provincial scale represent a complex and costly undertaking. To maximize efficiencies and control costs, North South Consulting Inc. et al (2007) recommend building on existing monitoring networks, which already provide information on some AEH components.

The Alberta Environmentally Sustainable Agriculture (AESA) stream water quality sampling program has involved monitoring of 23 streams and was designed to document the effects of agriculture on stream water quality over time. The AESA network comprised streams selected based on similarities in soils and landscapes attributes of their watersheds and the range of agricultural intensities and practices in these watersheds (Anderson et al. 1999). The AESA program focused on surface water quality indicators known to be influenced by agricultural intensity (e.g., nutrients, pesticides, bacteria) (e.g., Anderson et al.1998), but did not include other measures of AEH. 


\subsection{OBJECTIVES}

The intent of this small pilot project was to scope the feasibility of adding sediment and non-fish biota to AESA stream monitoring and to make a preliminary evaluation of the data.

Specific objectives were to:

- Test the suitability and practicality of monitoring techniques at a few sites;

- Provide some preliminary information for sediment chemistry and biological communities;

- Produce recommendations for future AEH monitoring of agricultural streams. 


\subsection{METHODS}

\subsection{Sampling Sites}

The pilot study, which took place in August - September 2006, focussed on three agricultural streams: Strawberry Creek and the Blindman River in the Boreal Transition ecoregion and Rose Creek in the Western Alberta Upland. The original classification of agricultural intensity relied on 1991 Statistics Canada census data (Anderson et al.1998) data pertaining to chemical and fertilizer expenses and manure production and the drainage basins spanned the range of agricultural intensity: "low" (Rose Creek), "moderate" (Blindman River) and "high" (Strawberry) (Table 1, Figure 1). Census data from 1996, 2001 and 2006 indicate that agricultural intensity in the Blindman River drainage basin has fluctuated between "medium" and "high", while that in Strawberry Creek has fluctuated between "high" and "medium" (Lorenz et al., 2008( draft). Blindman retains a "medium" rating, but Strawberry Creek is now also rated as "medium". Nutrient levels, particularly dissolved nutrients, for the period of record (Table 1) are generally lowest in Rose and highest in Strawberry Creek, a situation which has been documented in every year of monitoring (e.g., Anderson et al. 1998, Anderson 1997, 1998, Carle 2001, Depoe and Westbrook 2003, Depoe, 2004, Depoe 2006 a,b, Lorenz et al., 2008( draft).

Sampling of sediments and biological community took place near the Water Survey of Canada gauging station which has also been the marker for the water quality sampling sites.

Table 1 Summary of background information on the three AESA streams selected for the pilot study

\begin{tabular}{|c|c|c|c|}
\hline & ROSE CREEK & BLINDMAN RIVER & STRAWBERRY CREEK \\
\hline Drainage basin size $\left(\mathrm{km}^{2}\right)$ & 559 & 353 & 592 \\
\hline Ecoregion & Western Alberta Upland & Boreal Transition & Boreal Transition \\
\hline Major watershed & North Saskatchewan River & Red Deer River & North Saskatchewan River \\
\hline \multicolumn{4}{|l|}{ Agricultural Intensity } \\
\hline Anderson et al. (1999) based on 1991 census & Low & Medium & High \\
\hline \begin{tabular}{|l|l|l|} 
Lorenz and Depoe(2009).('average' of 1996, 2001,2006 census) \\
\end{tabular} & Low & Medium & Medium \\
\hline Mean daily discharge $2006(\mathrm{cms})$ & 1.372 & 0.559 & 0.326 \\
\hline \multirow[t]{2}{*}{ Nutrient Concentrations (mg/L ) (Lorenz et al. draft) } & \multicolumn{3}{|c|}{ Nutrient data from 1995 to 2006} \\
\hline & Minimum-Median-Maximum & Minimum-Median-Maximum & Minimum-Median-Maximum \\
\hline TP & $0.062 \quad 0.234 \quad 0.955$ & $0.136 \quad 0.297 \quad 0.536$ & $0.189 \quad 0.692 \quad 1.249$ \\
\hline TDP & $0.0180 .030 \quad 0.058$ & $\begin{array}{lll}0.058 & 0.152 & 0.338 \\
\end{array}$ & $\begin{array}{llll}0.047 & 0.0127 & 0.319\end{array}$ \\
\hline TN & $0.900 \quad 1.332 \quad 2.551$ & $1.305 \quad 1.973 \quad 3.495$ & $1.186 \quad 3.296 \quad 4.628$ \\
\hline TKN & $0.862 \quad 1.276 \quad 2.453$ & $1.079 \quad 1.702 \quad 2.857$ & $0.894 \quad 2.516 \quad 3.203$ \\
\hline$\left(\mathrm{NO}_{2}^{-}+\mathrm{NO}^{3}\right)-\mathrm{N}$ & $0.011 \quad 0.016 \quad 0.036$ & $0.032 \quad 0.130 \quad 0.271$ & $0.136 \quad 0.367 \quad 0.859$ \\
\hline$\left(\mathrm{NH}_{4}^{+}\right)-\mathrm{N}$ & $0.023 \quad 0.054 \quad 0.084$ & $0.061 \quad 0.227 \quad 0.560$ & $0.075 \quad 0.387 \quad 0.756$ \\
\hline
\end{tabular}

Pilot Study to Evaluate the Practicality of Biological Monitoring of Small Agricultural Streams 
AESA Stream Survey

Watershed Locations

Watershed

City

1. Hines Creek

2. Grande Prairie Creek

3. Kleskun Drain

4. Paddle River

5. Wabash Creek

6. Tomahawk Creek

7. Strawberry Creek

8. Buffalo Creck

9. Stretton Creek

10. Blindman River

11. Rose Creek

12. Haynes Creek

13. Threehills Creek

14. Ray Creek

15. Renwick Creek

16. Crowfoot Creek

17. New West Coulee

18. Drain S-6

19. Battersea Drain

20. Prairic Blood Coulec

21. Trout Creek

22. Meadow Creek

23. Willow Creek

\section{Watershed Type}

\section{Imigation Stream}

Low Agricultural Intensity

Moderate Agricultural Intensity

High Agricultural Intensity

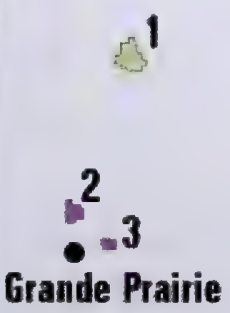

Grande Prairie
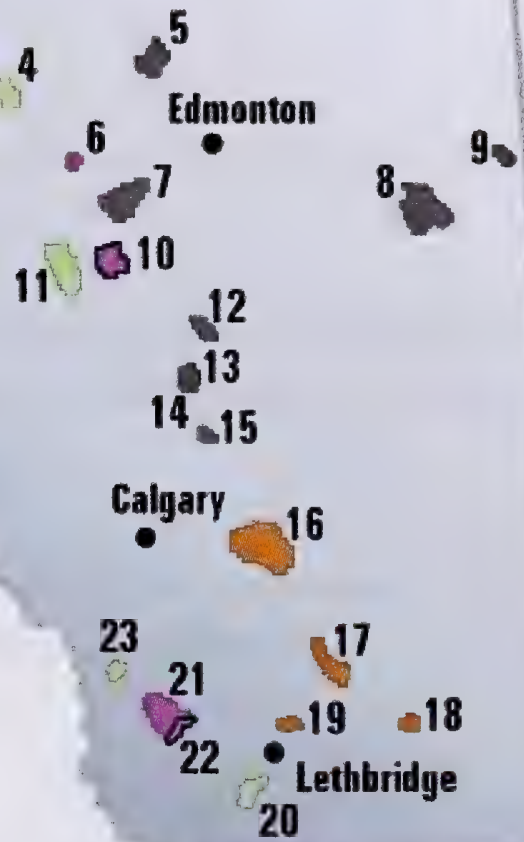

Figure 1 Agricultural watersheds monitored under the Alberta Environmentally Sustainable Agriculture (AESA) program 


\subsubsection{Field Measurements}

Field measurements and observations, based on Barbour et al. 1999, Jones et al. 2004, and Stambaugh et al. 2006 protocols were carried out at each site. The sampling reach was defined as 6 times bank full width, and three transects were established: Transect (T1) at the lower (downstream) end of the reach, T2 in the middle and T3 at the upper (upstream) end. Wetted width, bank full width, depth, mean flow velocity were measured along each transect; instantaneous discharge was estimated from these measurements. Multi-probe readings of DO, percent DO saturation, conductivity, $\mathrm{pH}$ and temperature were recorded along five points on T1. Water samples were collected from that reach. Reach characteristics such as stream nature (i.e., riffle, run, pool or pool/back eddy), \% macrophyte coverage and dominant taxa, substrate composition (e.g., \% cobble, gravel, sand based on visual estimates) and substrate embeddedness were recorded for each transect. Bank characteristics such as bank stability, degree of undercutting, dominant riparian vegetation and terrestrial canopy cover were recorded for a $10 \mathrm{~m}$ strip centered on each transect. A summary of field observations recorded during the pilot is provided in Appendix 1.

\subsubsection{Benthic Invertebrates}

D-frame kick nets were used to collect invertebrates. One-minute kick samples were collected at each of the three transects for the study reach. Sampling was carried out by kicking the substrate, and moving in an upstream direction across the channel while sweeping the net over the disturbed substrate. If the net appeared to clog, sampling was interrupted; the net emptied and sampling resumed for the remainder of the time. The three one-minute transect samples were combined to form one composite sample per study reach. Although most of Alberta Environment's (AENV) benthic invertebrate monitoring of large rivers has relied on nets of $210 \mu \mathrm{m}$ mesh size, rapid assessment procedures which are popular in some Canadian and US monitoring programs of smaller streams (e.g., Jones et al. 2004) use much coarser mesh sizes. To evaluate the relative merits of invertebrate data obtained with different mesh sizes, two sets of nets $(210 \mu \mathrm{m}$ and $400 \mu \mathrm{m}$ mesh size) were used at each site.

Samples were transferred to plastic bags and preserved with buffered formaldehyde shortly after collection. Three replicate samples were collected with each net at the Blindman River site to describe variability. Each replicate consisted of three one-minute kicks collected along each transect and pooled to form a composite sample.

\subsubsection{Epilithic Algae}

Epilithic algae for chlorophyll- $a$ determination were scraped from rocks using the template method (Alberta Environment 2006). Scrapings from a $4 \mathrm{~cm}^{2}$ template were taken from each of three rocks taken to form a replicate sample. A replicate sample was generated along each transect, yielding three replicates per reach. Algal material was placed on a GF/C filter, sprinkled with $\mathrm{MgCO}_{3}$, and then wrapped in aluminum foil, kept 
on ice until return to the field office and then frozen. Triplicate samples (two additional replicates per transect) were taken at the Blindman River site for QA/QC purposes.

Epilithic algae for taxonomic analysis were also obtained using the template method, but in this case scrapings ( $4 \mathrm{~cm}^{2} /$ scraping) from nine rocks (three per transect) were combined to form one composite sample. The sample was preserved with Lugol's solution and five drops of formaldehyde. Additional samples (three replicates, collected as described) were obtained from the Blindman River to describe variability in taxonomic data.

\subsubsection{Phytoplankton}

Water was collected from five cross channel points along the lower (T1) transect and pooled in a carboy. The sample was well mixed and poured off into 1L dark Nalgene containers for Chl- $a$ analysis and $100 \mathrm{~mL}$ phytoplankton jars. Chl- $a$ samples were filtered on $\mathrm{GF} / \mathrm{C}$ filters in the laboratory; $\mathrm{MgCO} 3$ was sprinkled on the filter before freezing.

Phytoplankton samples for taxonomic analysis were preserved in the field with Lugol's solution and a few drops of formaldehyde. Two additional samples were poured off from cross sectional composite samples collected sequentially (over a period of approximately half an hour) at the Blindman River site to assess variability over time.

\subsubsection{Sediment}

One composite sediment sample per site was collected from depositional areas along the three transects, using the 'spoon method' as described in Alberta Environment (2006). These composite samples, destined for particle size and nutrient analyses, were stored in plastic bags and kept cool until delivery to the analytical laboratory.

\subsection{Sample Processing Methods}

\subsubsection{Benthic Invertebrate Samples}

The zoobenthic samples were washed over a 2, and a $0.210 \mathrm{~mm}$ sieve. The coarse fraction was sorted in its entirety; the material washed onto the fine sieve was subsampled using a Marchant Box (Marchant 1989). A minimum of 500 organisms were sorted, or at least three of the 100 cells in the Marchant Box were processed. This was needed to obtain a minimum level of precision deemed necessary for the (sub)sampling invertebrates (see Elliott 1977, Wrona et al. 1982). All invertebrates were sorted under a dissecting microscope (magnification range 6 to 50X).

Specimens were identified to genus or species where possible, according to Edmunds et al. (1976), Wiggins (1977), Merritt and Cummins (1996), Clifford (1991), Thorp and Covich (2001), and others using the most current taxonomic designations available (See Taxonomic References)

Benthic Invertebrate taxonomic analyses are presented in Appendix 2. 


\subsubsection{Epilithic and Plankton Algal Taxonomy, and Chlorophyll-a Analyses}

Chlorophyll- $a$ was determined fluorometrically after acetone extraction at the Analytical Chemistry Laboratory, Alberta Research Council, Vegreville. Phaeophytin- $a$, a degradation product of chlorophyll was measured in epilithic samples. Results are reported as $\mathrm{mg} / \mathrm{m}^{2}$ for epilithic samples and $\mathrm{mg} / \mathrm{m}^{3}$ for plankton samples.

Non-diatoms (soft algae) and diatoms were analyzed separately. Depending on their concentration, non-diatoms samples were diluted first. To determine the appropriate dilution, the original samples were screened to assess the densities of algae and non-algal matter (debris and particulate matter). Aliquots of the appropriately diluted samples were allowed to settle overnight in sedimentation chambers following Utermöhl's procedure described in Lund et al. (1958). Algal units were counted from a minimum of four transects on a Zeiss Axiovert $40 \mathrm{CFL}$ inverted microscope. Counting units were individual cells, filaments, or colonies depending on the organization of the algae. Both diatoms and non-diatoms were counted. For soft algae, between 250 and 300 units were counted at 500X magnification; a number transects were scanned at $250 \mathrm{X}$ for larger algae. For diatoms, a minimum of 250 was set as the target. At this stage, diatoms were not identified to species or genus, but recorded as "diatoms", and were later identified to species from prepared slides.

Preparation of diatom slides consisted of digesting sub-samples using concentrated nitric acid and hydrogen peroxide and washing several times (by centrifuging) with distilled water. A few drops of the diatom slurry were placed on a cover slip and allowed to evaporate overnight. Once dry, the diatoms were mounted in Naphrax and identified using 1000 to $1500 \mathrm{X}$ magnifications (under oil immersion) on a Zeiss Axioskop 40 compound microscope. A minimum of 500 diatom frustules were counted on each slide. The diatom counts on the slides were converted to density based on the number of transects covered during the fresh (Utermöhl) counts.

Biomass was calculated from recorded abundance and specific biovolume estimates, based on geometric shapes (Rott 1981), assuming a specific gravity of one. The biovolume $\left(\mathrm{mm}^{3} / \mathrm{m}^{3}\right.$ fresh weight) of each species was estimated from the average dimensions of 10 to 15 individuals. The biovolumes of colonial taxa were based on the number of individuals in a colony. All calculations for cell concentration (units $\left./ \mathrm{cm}^{2}\right)$ and biomass $\left(\mu \mathrm{g} / \mathrm{cm}^{2}\right)$ were performed with Hamilton's (1990) computer program.

Taxonomic identifications of soft algae were based primarily on Anton and Duthie (1981), Entwisle et al. (2007), Findlay and Kling (1976), Huber-Pestalozzi (1961, 1972, 1982, 1983), Tikkanen (1986), Prescott (1982), Whitford and Schumacher (1984), Starmach (1985), Komarek \& Anagnostidis (1998, 2005), and Wehr and Sheath (2003). Diatom identifications were based primarily on the following texts and supplemented with other publications: Krammer and Lange-Bertalot (1986, 1988, 1991 a,b), Reavie and Smol (1998), Cumming et al. (1995), Bahls (2004), Camburn and Charles (2000), Fallu et al. (2000), Patrick and Reimer (1966, 1975), Siver and Kling (1997), and Siver et al. (2005). 
Results of epilithic and plankton algal community data are shown in Appendix 3 and 4, respectively.

\subsubsection{Sediment Chemistry}

Particle size, organic carbon, total nitrogen (as TKN) and total phosphorus were analyzed in sediments collected at each site. Method descriptions are outlined below.

Total Phosphorus: the sediment sample is digested with sulfuric acid, potassium sulphate and a mercury catalyst at $360^{\circ} \mathrm{C}$. All phosphorus species are converted to phosphate which is determined colorimetrically in an automated system by the molybdate-antimony tartrate-ascorbic acid method.

Total Kjeldahl Nitrogen: sediment sample is digested with sulfuric acid, potassium sulphate and a mercury catalyst at $360^{\circ} \mathrm{C}$. Organic nitrogen is converted to ammonia, which is determined colorimetrically in an automated system by the phenate method.

Organic Carbon in sediments is determined by the difference between total carbon and inorganic carbon. Total carbon in sediments is obtained by placing a known amount of sample in a crucible and combusting the sample at $950^{\circ} \mathrm{C}$. The carbon dioxide formed is measured in an infrared cell. Inorganic carbon in sediment samples is obtained by acidifying a known amount of sample with excess sulphuric acid. The evolved $\mathrm{CO}_{2}$ is trapped in sodium hydroxide. The partial alkalinity of samples is compared to $\mathrm{CaCO}_{3}$ standards to determine total carbonate and inorganic carbon.

Particle size distribution in sediments is measured using the hydrometer method and is based on M.R. Carter (1993) as described in Soils Sampling and methods of Analysis, 507:509. Lewis Publishers.

\subsection{Data Analysis}

This small dataset did not lend itself to statistical analyses (e.g., comparison among sites). Therefore, evaluation of results relied primarily on visual appraisal of graphs and tables. Simple metrics were calculated; these included taxonomic diversity (i.e., number of major taxonomic groups, genera, or individual taxa) and absolute and proportional (percent) abundance and biomass (algae, only) at various taxonomic levels. An extensive exploration of merits of a broad range of 'metrics' was not justified here because of the limited data set.

However, the applicability of recent work by Potapova and Charles (2007), involving the development of a nutrient preference index for diatoms, was tested with the diatom data from this pilot study. The authors compiled an indicator species list by defining the nutrient preference range for riverine diatom species in the United States based on species distribution and nutrient data. Data used in this process are those from the U.S. Geological Survey National Water Quality Assessment program. Species which had the highest mean relative abundance and frequency of occurrence at $\mathrm{TP} \leq 10 \mu \mathrm{L}^{-1}$ were designated as 'low TP or LP', those with TP $\geq 100 \mu \mathrm{L}^{-1}$ as 'high TP or HP', those with

Pilot Study to Evaluate the Practicality of Biological Monitoring of Small Agricultural Streams in Alberta 
$\mathrm{TN} \leq 0.2 \mathrm{mgL}^{-1}$ were designated as 'low TN or LN', those with $\mathrm{TP} \geq 3 \mathrm{mgL}^{-1}$ as 'high TN or HN'. A high index value indicates that species which thrive under high nutrient conditions prevail, and vice versa.

Indices for total phosphorus (P-preference index) and total nitrogen (N-preference index) indicators were calculated as:

P-Preference index $=\underline{10 \mathrm{HP}}$ HP+LP

$\mathrm{N}$ - Preference index $=\underline{10 \mathrm{HN}}$ $\mathrm{HN}+\mathrm{LN}$

The indices for our stream data were calculated using species abundance data. In addition, absolute and relative abundance of species with high, low, and unclassified nutrient preferences were graphed. 'Unclassified' species were those which did not appear or did not receive a rating in Potapova and Charles (2007). 


\subsection{RESULTS AND DISCUSSION}

\subsection{General Site Description}

As mentioned earlier (Table 1), the three watersheds are located in different ecoregions and they drain lands that are farmed with different intensity. In part as a result of these different features, there were some important site-specific differences which would be expected to influence biological communities.

The Rose Creek site had mostly erosional substrate (cobble, gravel) with small depositional patches (sand and fines); at the time of sampling there was measurable flow (Appendix 1). The Blindman River held both types of habitat, although depositional substrate was dominant at the sampling site. There was some flow at the site, but it was not measurable. The Strawberry Creek site was dominated by depositional substrates and there was no flow at the time of sampling.

At the time of sampling water was well oxygenated, alkaline, and conductivity ranged from $316 \mu \mathrm{S} . \mathrm{cm}^{-1}$ in Rose Creek to $611 \mu \mathrm{S} . \mathrm{cm}^{-1}$ in Strawberry Creek. Macrophytes were present at all sites, but they were abundant (25-50\% coverage) at only one transect on Strawberry Creek. Bank stability was considerably affected by uncontrolled access of cattle to the Blindman River. Livestock trails were visible, but to a much lesser extent at the Rose Creek site. Strawberry Creek had unstable banks, including some steep banks with no vegetation and erodable soils; there was no evidence of cattle activity at this site.

Riparian cover at Rose Creek was comprised of sedges, shrubs, deciduous and coniferous trees, and a relatively small amount of bare soil. At the Blindman River site grasses, sedges and shrubs dominated along with bare soil especially where cattle accessed the stream. Strawberry Creek had a mix of grass, sedges and shrubs with some deciduous trees. Terrestrial canopy cover over the wetted area was low at all sites. A beaver dam was present about $100 \mathrm{~m}$ upstream of the upper transect on the Blindman River, and about $1 \mathrm{~km}$ downstream of the lower transect on Strawberry Creek. No beaver dams were observed in the immediate vicinity of the Rose Creek site.

\subsection{Practical Considerations about the Pilot Sampling}

Following are general observations regarding time commitment, training requirement, and suitability/practicality of sampling techniques.

It took each of three staff approximately 6,7 and 9 hours to perform field data and sample collections at Rose Cr., Strawberry Cr., and the Blindman River, respectively. Time estimates for this pilot study are probably in excess of what would be required if sampling was part of routine monitoring. Note that the Blindman River, which took the greatest amount of time, involved much additional sampling (triplicate sampling of benthic invertebrates and algae).

Field measurements such as GPS readings, hydrometric measurements, and multi-probe readings require familiarity with equipment and procedures, but was otherwise easy to 
standardize. The documentation of the various reach and bank characteristics was somewhat more difficult to standardize because it involves visual observations and qualitative measures.

Collection of benthic invertebrates with kick nets was the most practical approach considering the wide range of variability in depth, substrate type and flow conditions expected in streams across Alberta. Both kick nets ( 210 and $400 \mu \mathrm{m}$ mesh size) performed well in Rose Creek which had coarse substrates. Clogging of the nets with fines was an issue in the Blindman River and Strawberry Creek which are more depositional in nature. Kick nets only allow qualitative sampling (i.e., not quantitative). Fixed-time sampling ( 3 minutes per sample in this pilot study) is one way of standardizing the samples. However, additional factors need to be standardized among sites, samplers, and over time to achieve reasonably consistent sampling. These include the intensity of kicking, the velocity with which the net is swept back and forth, and the sampler's travel speed. Staff training and reliance on experienced staff are critical in the collection of samples that can be compared over time and among sites.

Suitable rocks for epilithic algae sampling were eventually found at all 3 stream sites. However, the time involved in finding rocks was greatest at the Strawberry Creek site which was more depositional in nature than the two other sites. Alternative sampling approaches are needed to sample sandy or muddy sites devoid of rocks. The use of a small ( $2.5 \mathrm{~cm}$ diameter) core is currently being tested to sample such fine-grained substrates.

Sampling of water quality, including phytoplankton and sediments was straightforward at all sites.

If sampling of AEH indicators in small streams were to become part of a regular program, staff training and consistent involvement of experienced staff would be critical in achieving consistency in site assessments and acquisition of standardized samples. Based on the experience of this pilot study it is estimated that sampling of water, sediments, benthic invertebrates (one kick net), epilithic algae and conducting the field measurements would require a minimum of 2 to 3 hours from a well-trained crew of three.

\subsection{Sediment Analyses}

Sediment analyses are summarized in Table 2. Particle size distribution illustrates some of the habitat differences described earlier. Sediment collected from Rose Creek was mostly sandy, whereas sediment from the other two sites also contained a substantial amount of silt and clay. Organic carbon was low at all sites. 


\section{Table 2 Sediment particle size and nutrient levels}

\begin{tabular}{l|c|c|c}
\hline & Rose Creek & Blindman River & Strawberry Creek \\
\hline Sand \% & 98 & 66 & 73 \\
\hline Silt \% & $<1$ & 17 & 13 \\
\hline Clay \% & 2 & 17 & 15 \\
\hline Organic Carbon \% & $<0.8$ & $<0.8$ & 0.8 \\
\hline Inorganic Carbon \% & 0.4 & 1.8 & 1.6 \\
\hline Total Carbon \% & 0.6 & 2.3 & 2.4 \\
\hline & & & \\
\hline Sediment TKN mg/kg & 259 & 1860 & 939 \\
\hline Sediment TP mg/kg & 504 & 842 & 541 \\
\hline
\end{tabular}

Consistent with the substrate type and level of agricultural intensity, Rose Creek had the lowest levels of total phosphorus and nitrogen. Blindman River sediments had the highest levels of nutrients, along with the highest percentage of silt and clay.

\subsection{Benthic Invertebrates}

\section{Comparison of sites}

Benthic invertebrates were abundant and diverse in the three streams (Appendix 2). In total, 128 taxa belonging to a wide variety of invertebrate taxonomic groups were recorded (e.g., Turbellaria, Nematoda, Oligochaeta, Hirudinea, Cladocera, Copepoda, Ostracoda, Amphipoda, Ephemeroptera, Plecoptera, Trichoptera, Diptera, Hemiptera, Coleoptera, Odonata, Mollusca, and Acari). Based on collections with both nets, the number of invertebrates was lower in Rose Creek than in Strawberry Creek and the Blindman River, in particular. However, taxonomic diversity was greater in Rose Creek and the Blindman River than in Strawberry Creek (Figure $2 a, b$, and e); this trend is likely related to differences in substrate sampled in the three streams (Appendix 1).

The invertebrates collected with the $210 \mu \mathrm{m}$ net at the Rose Creek site were dominated numerically by Chironomidae, Trichoptera, Ephemeroptera and Oligochaeta; other groups such as Plecoptera and small crustaceans (Cladocera, Copepoda, Ostracoda) were also well represented (Figure $2 \mathrm{~d}$ and e). Ephemeroptera, Plecoptera, and Trichoptera, often referred to as "EPT" are, for the most part, typical inhabitants of erosional substrates, and relatively good water quality, and they were most abundant and diverse in Rose Creek (Figure $2 \mathrm{c}$ ). Another typical inhabitant of hard bottom erosional substrates only encountered in Rose Creek was the mollusc Ferrissia rivularis (Appendix 2). Despite the dominance of erosional species, some typical inhabitants of depositional substrates included the burrowing mayfly Ephemera and small numbers of Ilyocryptus sordidus, a benthic cladoceran with special adaptations (haemoglobin) to low dissolved oxygen levels (Appendix 2).

The fauna from the Blindman River and Strawberry Creek site was dominated by small crustaceans, Oligochaeta, and Chironomidae. Although some of the crustaceans are planktonic (e.g., Daphnia, Chydorus, cyclopoid copepods), the typically benthic Ilyocryptus sordidus was abundant at these sites. Amphipoda (Hyallella azteca and 
Gammarus lacustris) were fairly abundant in the Blindman River, but they occurred in low numbers in Strawberry Creek. Ephemeroptera and Trichoptera were present at the Blindman River and Strawberry Creek sites although they were less diverse and abundant than in Rose Creek. Leptophlebiidae were the only Trichoptera found at the Strawberry Creek site. No Plecoptera were found in the Blindman River or Strawberry Creek.

The fauna from Rose Creek was indicative of a well oxygenated, erosional habitat with moderate nutrient levels; whereas the fauna from the Blindman River site suggested a mixed habitat, potentially with areas of low dissolved oxygen and generally with higher nutrient levels. Substrate, flow and dissolved oxygen conditions appeared to be even more restrictive in Strawberry Creek.

Although the variability in the number of benthic invertebrates in the Blindman River replicates was large, particularly in the $210 \mu \mathrm{m}$ mesh kick samples, the total number of taxonomic groups per sample and the relative contribution of major taxonomic groups to total numbers were less variable (Figure 2). This is relevant as it suggests that the manner in which kick samples were collected provided a repeatable indication of the invertebrate community composition. 

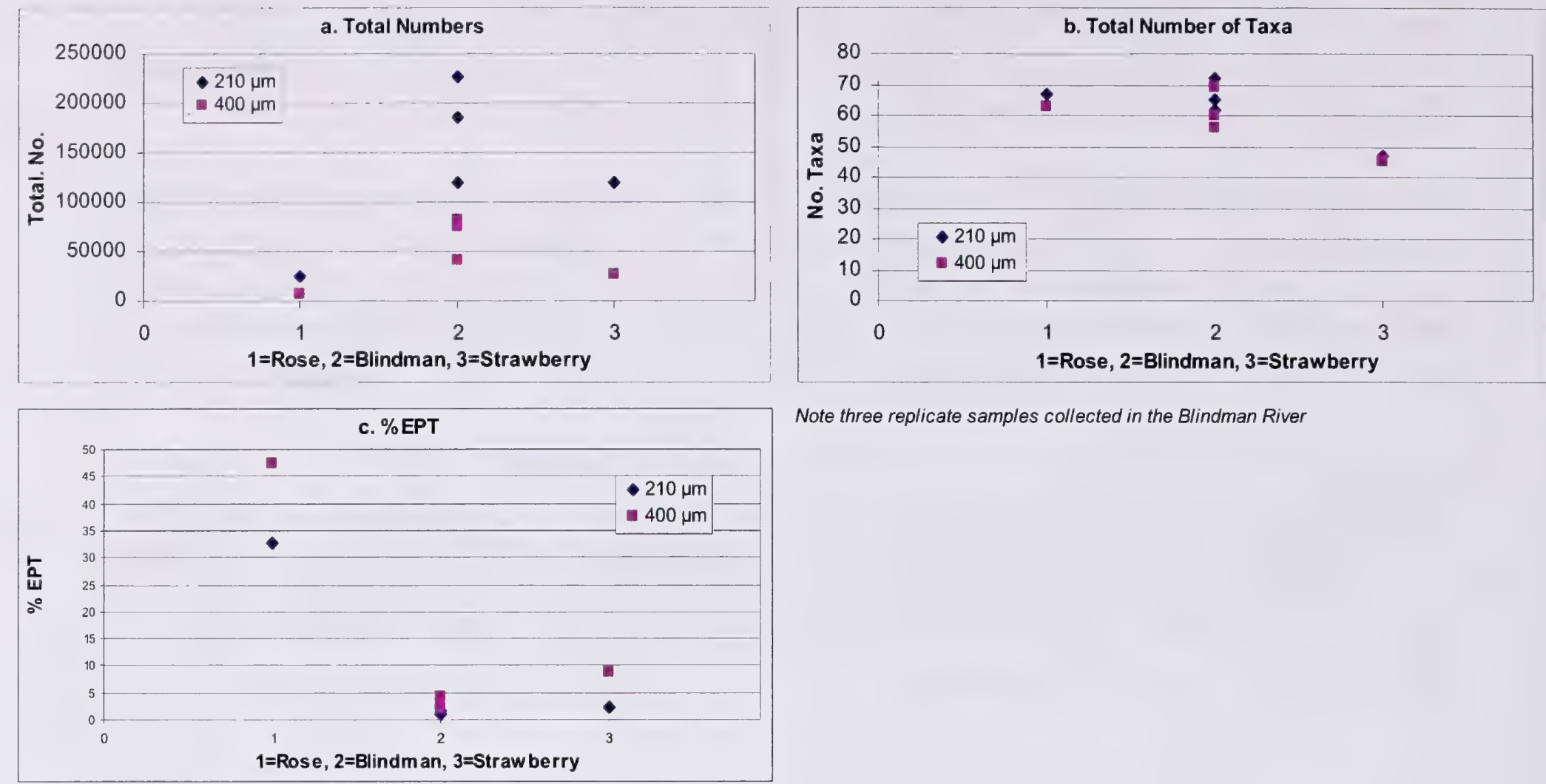

Note three replicate samples collected in the Blindman River
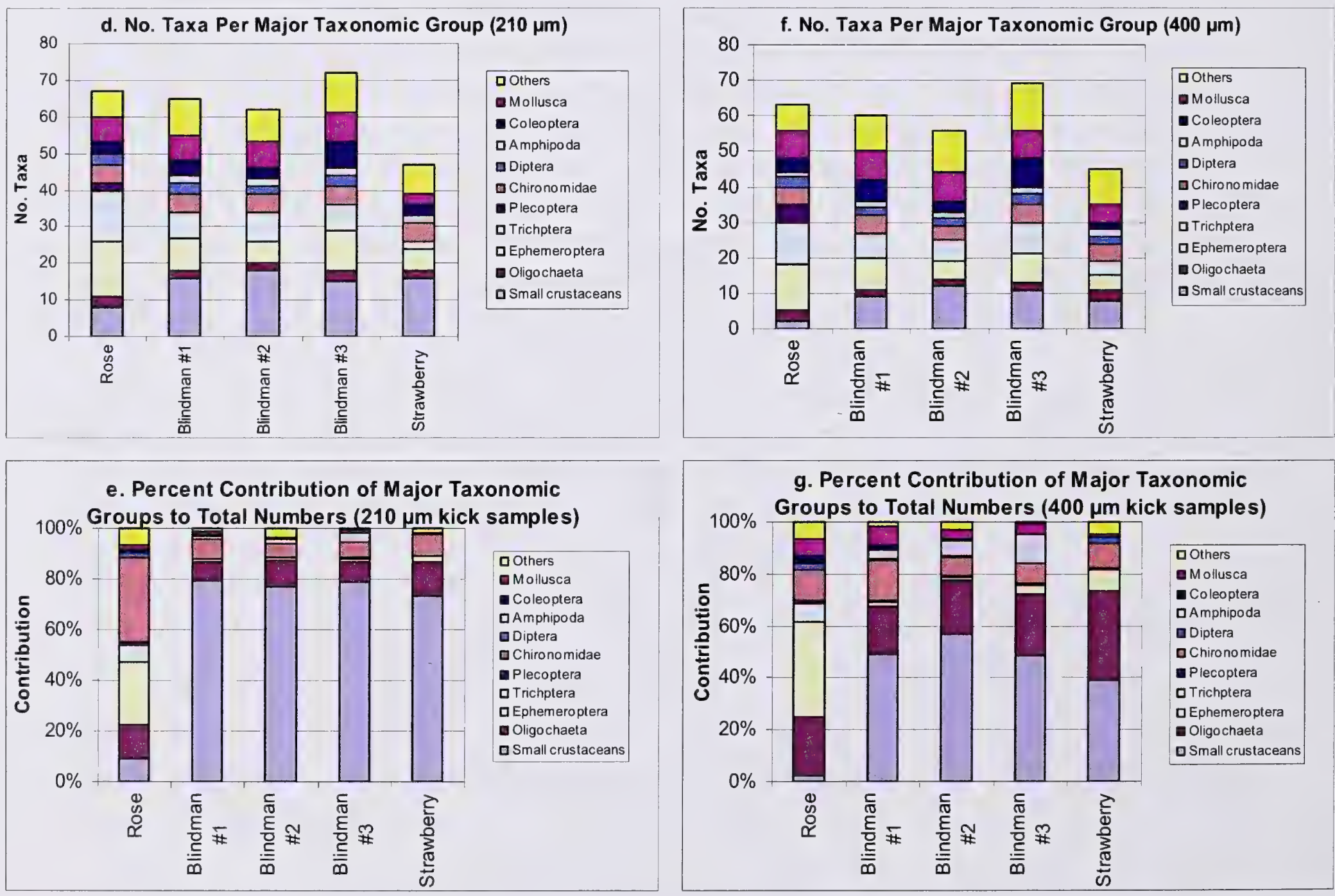

Figure 2 Benthic invertebrate data for three agricultural streams 
Differences among sites were consistent in samples collected with the 210 or $400 \mu \mathrm{m}$ kick net. However, as could be expected, total counts in the $210 \mu \mathrm{m}$ nets were consistently higher, or much higher, than in the corresponding $400 \mu \mathrm{m}$. The difference in taxonomic diversity between nets was not as pronounced, but samples collected with the finer net had 2 to 6 additional species, compared to those collected with the coarse net (Figure $2 \mathrm{a}$ and $\mathrm{b}$, Appendix 2).

Overall abundance and taxonomic diversity were lower in $400 \mu \mathrm{m}$ kick samples, but not all taxonomic groups were affected in the same way (Appendix 2):

- Many of the small crustaceans are small enough that they could pass through the $400 \mu \mathrm{m}$ mesh. As a result their number and diversity were considerably lower in the coarse kick net samples. With the exception of Simnocephalus, a rather large cladoceran, small crustaceans would have been missed altogether at the Rose Creek site with the $400 \mu \mathrm{m}$ mesh kick sampler.

- Interestingly, some molluscs (e.g., Valvatidae, Pisidium and Sphaeridae), were more numerous in the 400 than $210 \mu \mathrm{m}$ kick samples.

- Furthermore, some invertebrates were encountered only in the $400 \mu \mathrm{m}$ kick samples. These include the caddis flies Argaylea (Blindman), and Mystacides and Amphicosmoecus (Rose Creek) and the stoneflies Pteronarcys and Perlodidae (Rose Creek).

The differences in results between the two nets are likely due to the greater filtering capacity of the coarse net. The fine net clogs up faster and once this happens organisms can escape actively, or they can easily be washed away with water that does not pass through the net anymore.

Considering that general faunal differences among sites remained consistent regardless of the net used (i.e., interpretation of the data would have been similar), there are some advantages in using the coarse net. These include dealing with samples that have somewhat fewer, but larger organisms and the fact that the response to environmental disturbance of many larger organisms is often better understood that that of small crustaceans.

In a comparison of Bow River benthic invertebrate samples collected with Neill cylinder and the same two kick nets as in this study, Saffran and Anderson (2009) also noted the similarity in general longitudinal patterns obtained regardless of sampler, or mesh size used. However, because there is a historical invertebrate database that relied on Neill samples, and also because of advantages offered by routinely replicated Neill cylinder samples in statistical significance testing, recommendations were made to continue using Neill samplers in large provincial rivers.

There is no historical database for benthic invertebrates in agricultural streams and, hence, considering their apparent advantages, the use of $400 \mu \mathrm{m}$ kick nets, could be recommended in future sampling of small streams. Substrate can vary considerably in agricultural streams and kick nets could be used in erosional or depositional type substrates where Ekman grabs and Neill cylinders, respectively, would not be suitable. 


\subsection{Epilithic Algae}

Epilithic algae formed diverse species associations at the three sites. Diatoms (Bacillariophyceae) were the most diverse group with a total record of 85 different taxa belonging to 25 genera. Chlorophytes (Chlorophyceae) with 27 different taxa (12 genera) were the second most diverse, followed by Cyanobacteria with 15 different taxa (11 genera). Xanthophyceae and Dinophyceae were minor groups in terms of taxonomic diversity (one taxon each), abundance and biomass (Figure 3, Appendix 3).

Cell counts and biomass were greatest in Strawberry Creek (Figure $4 \mathrm{a}, \mathrm{b}$ ) and taxonomic diversity was lowest in Rose Creek (Figure $4 \mathrm{c}$ ). Diatoms and Cyanobacteria contributed most to cell counts and biomass, but the chlorophytes Spirogyra sp. and Cladophora sp. were important biomass contributors in one of the replicates taken at the Blindman River site and at the Strawberry Creek site, respectively (Figure 3 a, b, d, Appendix 3). Dominant diatoms in terms of biomass contribution were Cocconeis pediculus, Cocconeis placentula (Rose Creek), Cocconeis placentuala (Blindman River), Mastogloia smithii and Rhopalodia gibba (Strawberry Creek). Gloeotrichia (Cyanobacteria) and Cladophora sp. and Pediastrum boryanum (Chlorophyceae) dominated the biomass at Strawberry Creek (Appendix 3).

Replicates (each consisting of scraping from 3 rocks taken from each of the 3 transects) taken at the Blindman River site show that there are differences in the diversity, cell counts and calculated biomass (Figure 3), although the same major groups account for most of the abundance and diversity (Figure 4). The largest differences among the three replicates occur in biomass estimates and are due to the importance of one Chlorophyceae taxon (Spirogyra sp.) in one of the replicates and not the other (Figure 3 $\mathrm{d}$, Appendix 3). These differences are indicative of natural spatial heterogeneity, and QA/QC samples need to be incorporated in further stream sampling to verify how representative composite samples (3 rocks from each of 3 transects) are of the sampled stream reach. 

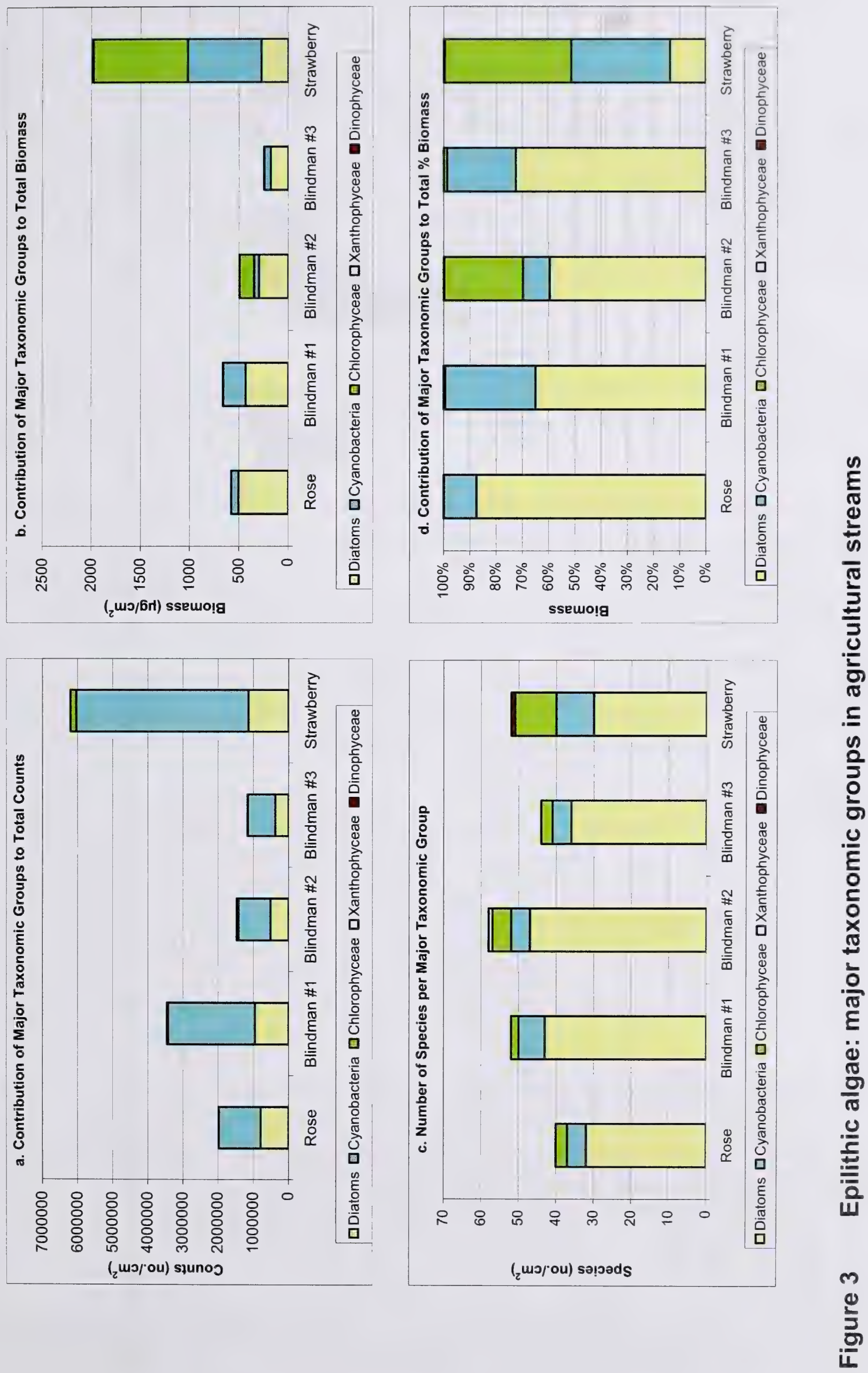

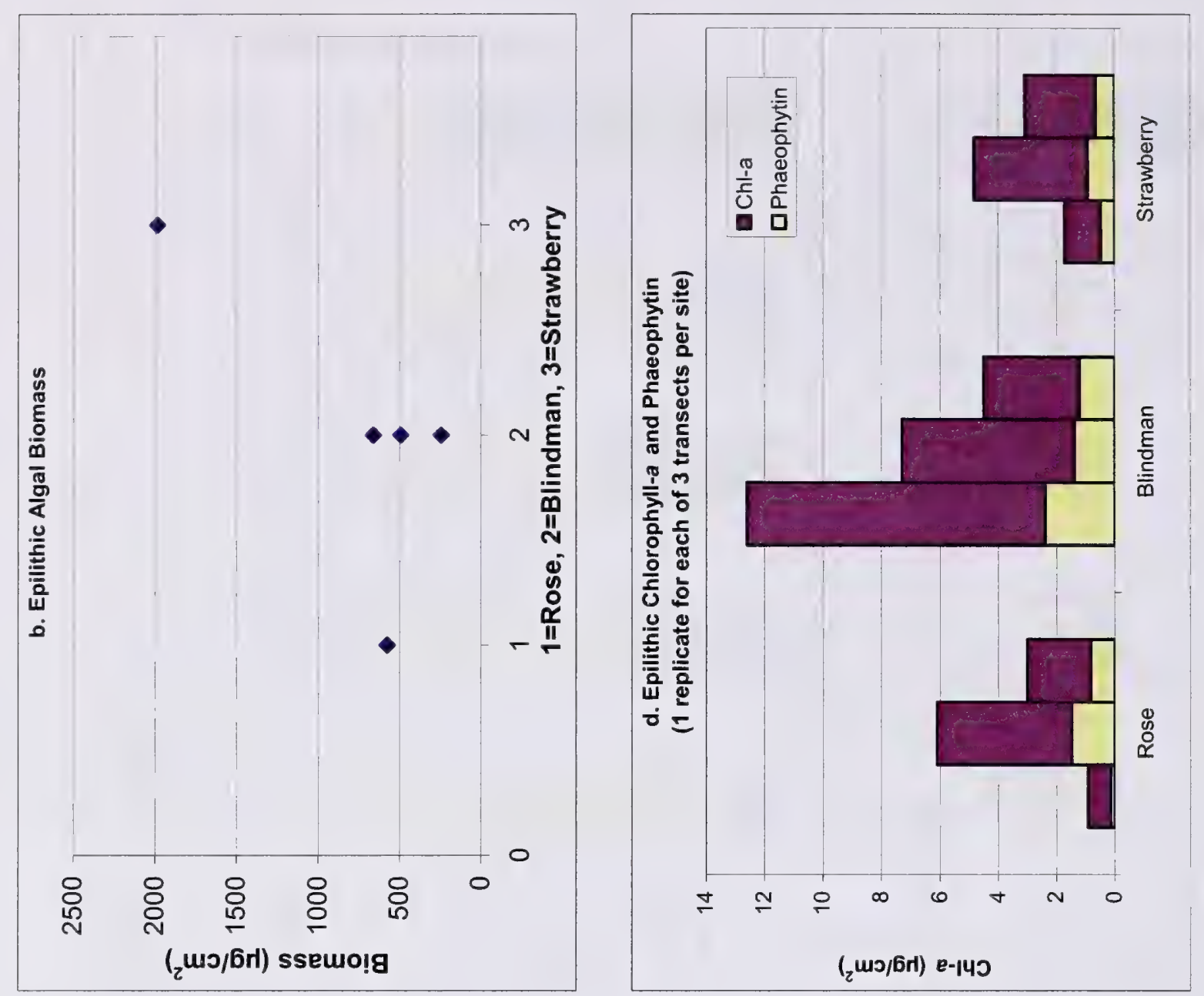

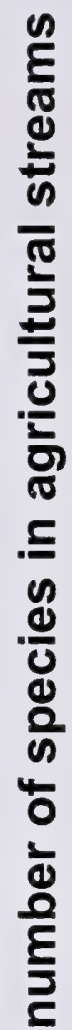
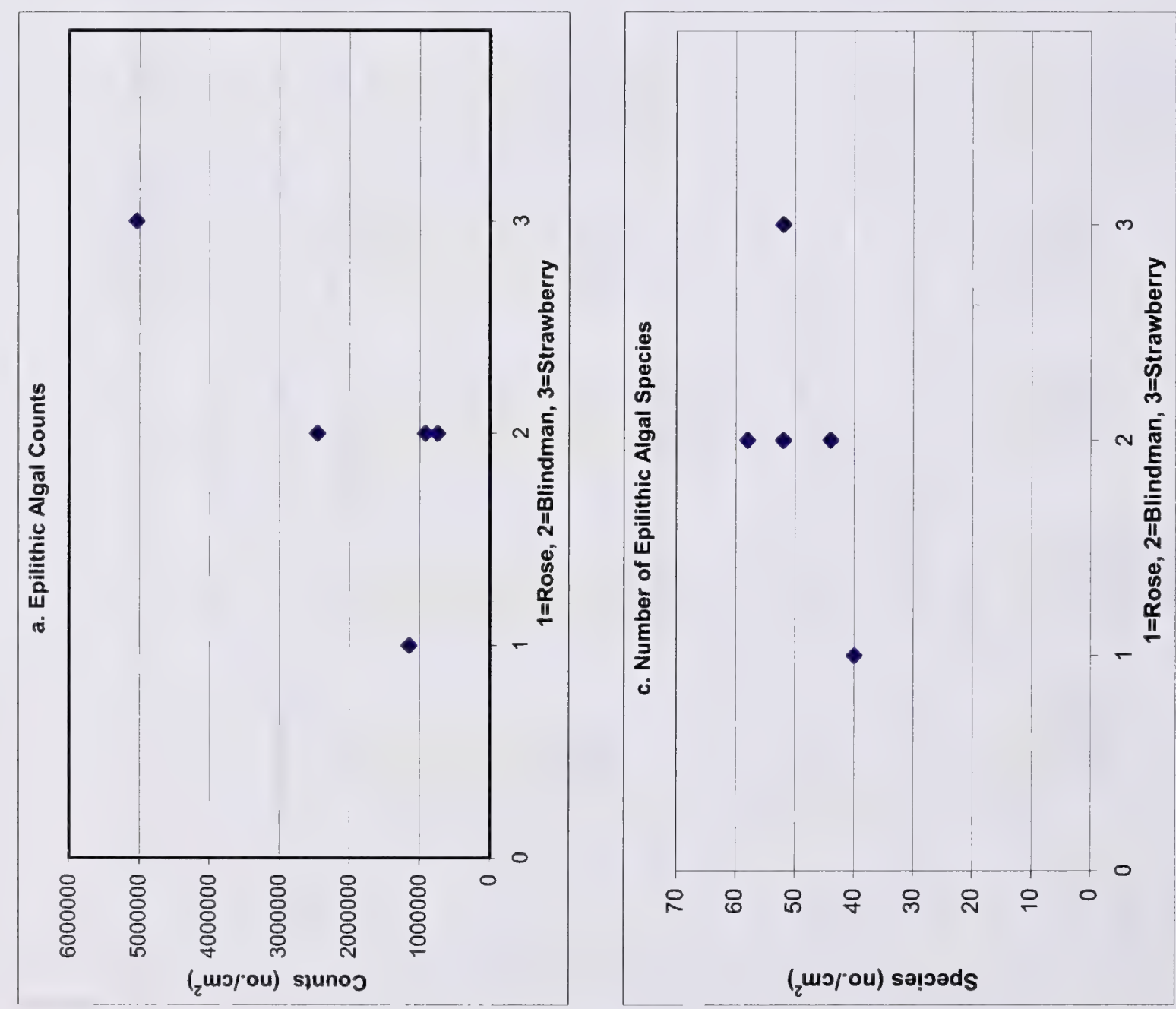
Chlorophyll levels varied substantially among the three replicate samples collected at each site and this illustrates the variability among transects (Figure 4d). In contrast with biomass estimates based on cell volumes (Figure $4 \mathrm{~b}$ ), chlorophyll- $a$ levels, which also are an indicator of biomass, were highest at the Blindman site and they were rather similar between Rose and Strawberry creeks (Figure $4 \mathrm{~d}$ ). Based on biomass calculated from cell volumes, Strawberry Creek had the highest biomass, but not based on Chlorophyll-a. The difference may be due to the dominance of Gloeotrichia at the site. Gloeotrichia forms mucilaginous colonies which can become very abundant and coat the substrate with a thick mucilaginous film. The chlorophyll- $a$ content, however, may be rather low as phycobilins, rather than chlorophyll- $a$, tend to be the dominant photosynthetic pigment in cyanobacteria. Hence, taxonomic information is an insightful complement to chlorophyll- $a$ measurements and contributes to a better understanding of biomass patterns in epilithic communities.

The relationship between diatom distribution and water quality is better documented than that of soft bodied algae (Potapova 2005), and diatoms are widely used to monitor river conditions in the United States and Europe (Potapova and Charles 2007, Tison et al. 2005).

Nutrient preference classes and $\mathrm{N}$ and $\mathrm{P}$ preference indices derived by Potapova and Charles (2007) were applied, to determine if diatom metrics could be used to differentiate among agricultural streams (Figure 5). This is one way in which relationships between nutrient levels and diatom species composition can be established in agricultural streams. Rose Creek had a lower index value for P (Figure 5 a) and N (Figure 5b) than the Blindman River and Strawberry Creek. In Strawberry Creek, and especially the Blindman River, species with high nutrient preference were considerably more abundant than species with low nutrient preference (Figure $5 \mathrm{c}$ to $\mathrm{d}$ ). In Rose Creek, numeric contributions of diatoms with high and low nutrient preferences were equivalent.

Total nutrient concentrations in our agricultural streams are rather high compared to the threshold ranges defined by Potopova and Charles (2007) (Table 1). For TP and TN the three pilot streams would all fall in the high nutrient range. If dissolved nutrients were considered, Rose Creek would fit in an intermediate range for TDP, while the Blindman River and Strawberry Creek still fit in the 'high' range. All streams would fall in the intermediate range for dissolved nitrogen. The differences among sites in nutrient preferences of diatoms are consistent with the differences in nutrient levels observed in water and sediments. This suggests that diatoms may be potential indicators of the trophic status of agricultural streams.

As noted by Potapova and Charles (2007), metrics derived from diatom-nutrient relationships tend to be more useful when they are derived from, and employed in regional-scale studies rather than continental or intercontinental studies. As more epilithic algal taxonomy information is associated with water quality information, it will become possible to refine such metrics for Alberta. 

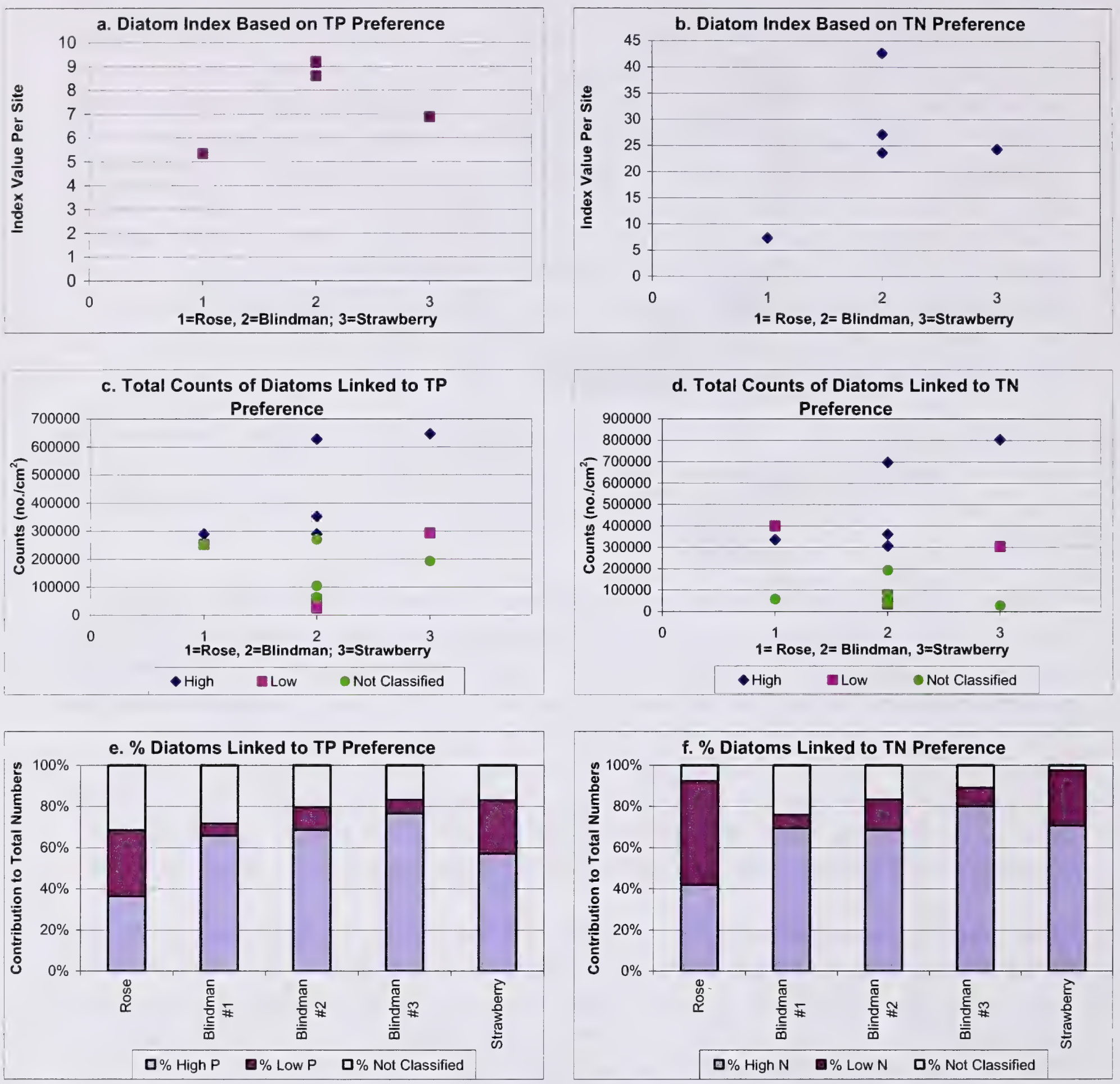

Figure 5 Diatom metrics for monitoring eutrophication in agricultural streams (after Potapova and Charles, 2007) 


\subsection{Phytoplankton}

A total of 50 individual taxa, comprising 35 different genera were recorded in phytoplankton samples. These include Cyanobacteria ( 5 taxa, 5 genera), Chlorophyceae (16 taxa, 12 genera), Chrysophyceae (5 taxa, 3 genera), Cryptophyceae (8 taxa, 3 genera), Euglenophyceae (3 taxa, 3 genera), Dinophyceae ( 3 taxa, 1 genus), and Bacillariophyceae (Diatoms: 10 taxa, 9 genera) (Appendix 4). The algal classes Chrysophyceae,

Cryptophyceae and Euglenophyceae which occurred in plankton were not found in the epilithic algal samples (Appendix 3).

The three replicates collected sequentially at the lower transect in the Blindman River showed a lot of variability in terms of cell counts, biomass, taxonomic diversity (taxa and genera) and specific taxonomic compositions (Figures 6 and 7). The degree of variability observed at the Blindman site encompassed the range of variability observed at the three sites. On average, cell counts, biomass and diversity were slightly higher at the Blindman site, but chlorophyll-a content (single sample) was noticeably higher (Figure 6). The high degree of variability observed in phytoplankton replicates from the Blindman site may be an indication of heterogeneity in phytoplankton communities of small streams. If this is the case, composite samples taken along the sampling reach would likely be better indicators of site conditions than single grab samples.

Cryptophytes and Euglenophytes were numerically abundant at all sites (Figure 7). Chlorophytes contributed most to the biomass and diversity of Rose Creek, and they were diverse and important contributors to the biomass in one of the Blindman replicates, but not the others. Chlorophytes were poorly represented at the Strawberry Creek site where Cyanobacteria were more abundant and diverse and contributed more to the biomass than at any other site. Cyanobacteria were not recorded in the phytoplankton from Rose Creek. Although diatoms were present at all sites, their abundance, biomass and diversity was rather low, especially compared to their importance in epilithic algal samples.

Individual species which were important biomass contributors at Rose Creek were Mougeotia (Chlorophyceae) and Cocconeis (Bacillariophyceae). Cryptomonas marsonii and Rhodomonas minuta (Cryptophyceae) and Euglena minuta were important at Strawberry Creek. At the Blindman River site, Chlamidomonas (Chlorophyceae), Cryptomonas erosa, Cryptomonas reflexa and Rhodomonas minuta (Cryptophyceae) and Euglena minuta (Euglenophyta) contributed substantially to the biomass of each of the three replicates. Other species were important in only one or two of the Blindman River replicates (e.g., Cocconeis, Cryptomonas erosa, unidentified Chrysophytes, Pediastrum boryanum, and Microspora).

The diversity of diatoms in phytoplankton samples was far too low to attempt to calculate Potapova and Charles' nutrient indices, or to relate diatom nutrient preferences to trophic status. 

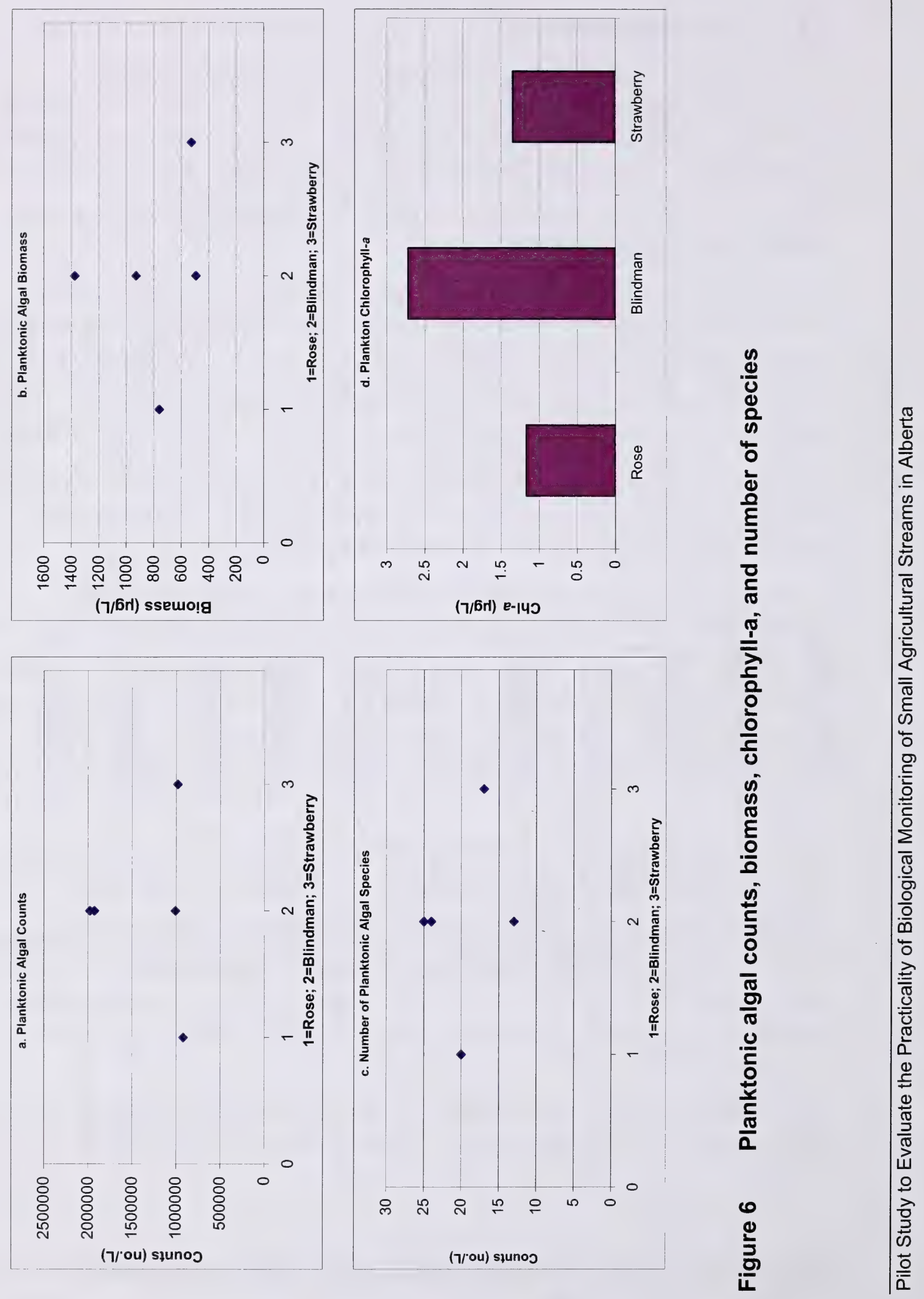

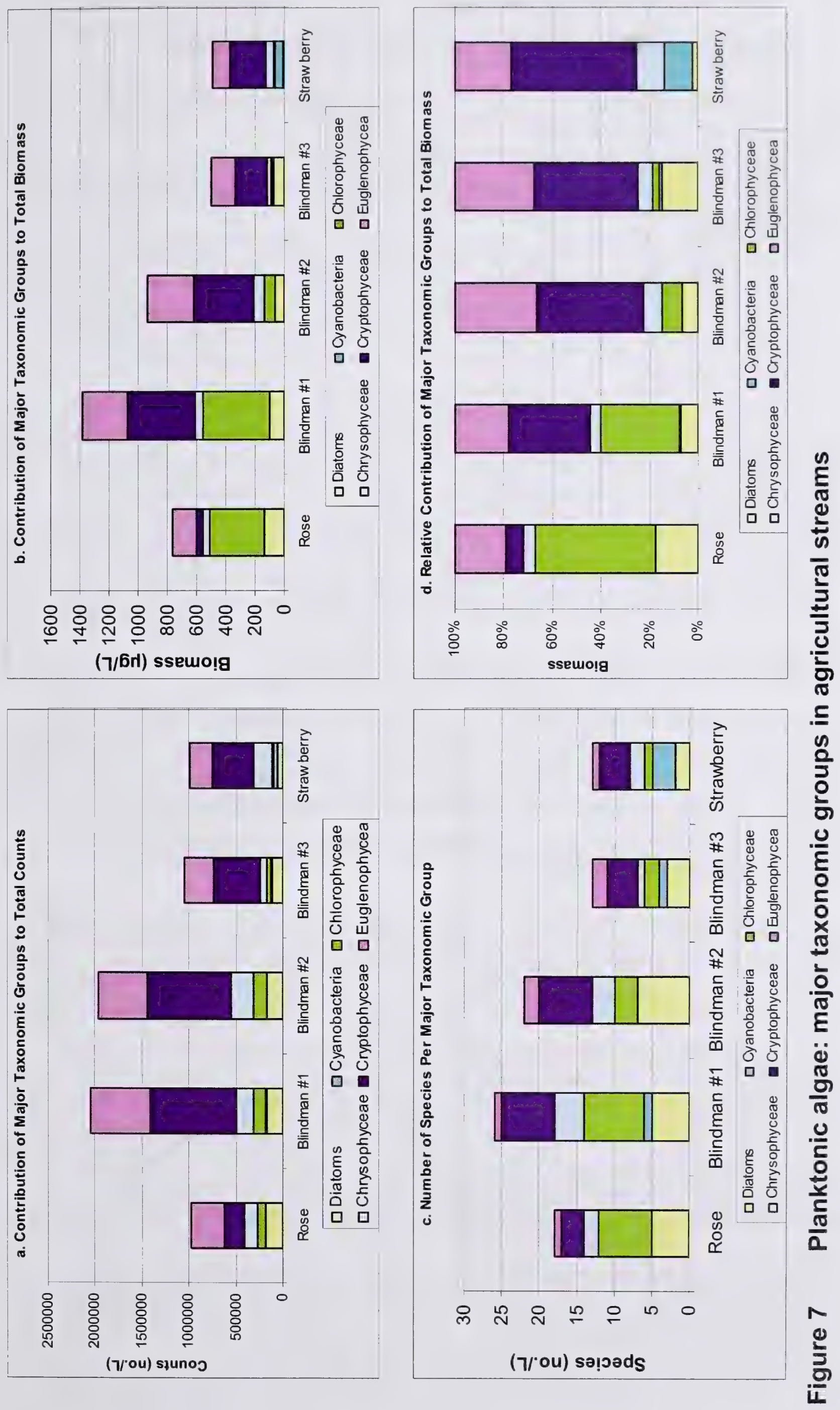

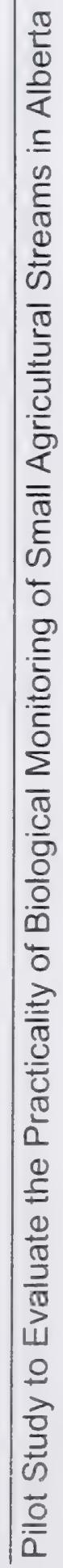




\subsection{GENERAL DISCUSSION}

\subsection{Suitability and Practicality of Monitoring Techniques}

The pilot study has illustrated the practicality of collecting biological communities and sediments from small Alberta streams.

- Kick net samples collected with a $400 \mu \mathrm{m}$ mesh offer some advantages over those collected with the $210 \mu \mathrm{m}$ and would be recommended for further sampling of small streams.

- Sediment and epilithic algal sampling procedures described in AENV (2006) were appropriate for agricultural streams. However, rocks suitable for epilithic algal sampling are often difficult to find in streams where depositional habitats prevail. The use of alternate sampling methods needs to be investigated further (e.g., "mini core" sampler).

- A critical goal of future sampling should be to ensure that samples and field information are collected in a consistent manner by experienced staff so that data are comparable over time and among sites. Although this is a general requirement of any sampling program, it applies particularly to AEH-related sampling components that are qualitative or semi-quantitative, or that rely, to some extent, on value judgement (e.g., benthic invertebrate kick samples, field observations of bank and reach characteristics). Sampling protocols need to be developed and included in the field manual, and staff training ensured.

\subsection{Selection of Potential Indicators of Health}

Benthic invertebrate and algal communities were diverse and abundant and offer good potential for further monitoring, along with water and sediment quality. Involvement of trained field staff and diverse scientific expertise through the full monitoring, evaluation, and reporting process is important. This expertise should complement and build on existing information when appropriate. Examples of existing information for benthic invertebrate and algal groups include:

- Benthic invertebrates have been used widely to document the ecological "health" or "integrity" of surface waters and they have been used extensively in biomonitoring programs (e.g., Klemm et al. 2003, Wright et al. 1995, Sylvestre et al. 2005). Ecological requirements and responses to various forms of disturbance, such as nutrient enrichment and toxicity, are relatively well understood (e.g., Hilsenhoff 1987, 1988, Mandaville, 2002, Carlisle et al. 2007). Biological criteria have been developed for many states in the U.S. (e.g., Younos 2002). There is obvious benefit to including benthic invertebrates in future biological monitoring of small streams. The composition and abundance of aquatic communities, such as benthic invertebrates, integrate changes in the chemical and physical environment, unlike water quality samples which represent conditions at the time of sampling.

- In addition, algal growth on bottom substrates is a very useful measure of the influences of nutrient enrichment in streams. For example, diatoms have also been widely used to assess various stressors on water quality (e.g., NAWQA data 
set used in Potapova and Charles 2005), species specific responses to nutrient enrichment, acidification, and discharge alterations have been documented and many indices have been developed to summarize responses to environmental changes (e.g., Soininen 2004, Potapova and Charles 2005, Tison et al 2005). Some researchers believe that diatoms are a more sensitive indicator to nutrient enrichment than benthic invertebrates (Steinberg and Schiefele 1988). The wealth of species-specific ecological information and the numeric and taxonomic dominance of diatoms in our epilithic algal samples, flags this group, in association with other epilithic algal species, as a potentially powerful biological indicator of eutrophication in small streams. This along with the relative ease to standardize collection and, compared to benthic invertebrates, more moderate sample processing cost makes epilithic algal communities a top candidate for further monitoring in small streams.

- In contrast, phytoplankton communities were the least diverse and most variable in terms of abundance and diversity. Diatoms were a relatively minor element of the phytoplankton associations, which were dominated by so-called "soft algae". Although soft algae are routinely monitored, their taxonomy and ecological requirements are not as well known (Potapova 2005). The phytoplankton species composition in our samples could be influenced, in part, by the time of year samples were collected (e.g., diatoms would likely be more abundant and diverse in spring e.g., Garnier et al. 1995). Overall phytoplankton in this pilot study appeared to yield less easily interpretable information than either benthic invertebrates or epilithic algae.

Information on sediment quality is needed to establish baseline conditions and further sampling of sediments in agricultural streams is recommended. There is a need to evaluate variables closely associated with agricultural activities, such as pesticides, pharmaceuticals and feed additives used in the livestock industry. In some cases, the evaluation of sediment quality data is hampered by the limited number of effects guidelines or thresholds to assess the significance of contaminant detections.

\subsection{Considerations for Future AEH Monitoring of Agricultural Streams}

Currently, one of the difficulties in assessing AEH in Alberta lies in defining the characteristics of 'healthy' aquatic ecosystems. Considerable progress has been made in the United States over the last 20 years to narrow down the concepts of biological "health" or 'integrity'. Following are key references extracted from Davis and Simon (1995):

- Biological integrity is defined as "...the ability of an aquatic ecosystem to support and maintain a balanced, adaptive community of organisms having a species composition, diversity, and functional organization comparable to natural habitats of a region" (Karr and Dudley 1981).

- It is recognized that entirely natural or unimpaired habitats may no longer exist, but an estimate of expected biological integrity in surface waters can be based upon "least impacted conditions" or "reference conditions".

- Least impacted reference conditions form the basis for developing biological goals, or biological criteria. 
The regional scale that is used to define biological criteria may vary among water body types, but ecoregions have been favoured for small to medium-sized streams by many researchers and agencies (e.g. Omernik 1995, Stoddard 2005, Tison 2005). Various stream types may exist within an ecoregion and in order to maximise the relevance of reference conditions, it is useful to classify streams based on natural hydrological features (e.g., stream order, drainage basin size, discharge patterns, contributing areas), and manmade features, in this case mostly related to non point sources (e.g., land use in watershed and along riparian areas, road crossings).

According to Hughes (1995), the number of reference sites needed to characterize reference conditions is a function of regional variability and size, the desired level of detectable change, resources and study objectives. Hughes proposed that 20 randomly selected sites from candidate reference sites in a given region provide a reasonable estimate of reference conditions. These selected sites could be subdivided in groups that account for different stream types.

The next and essential step is to acquire sufficient biological information from reference sites and match it with relevant chemical and physical characteristics of streams and watersheds. Such dataset would form the basis for developing biological criteria. Biocriteria may differ in nature, and, or numerical value depending on the ecoregion and type of stream (e.g., biocriteria based on Ephemeroptera, Plecoptera and Trichoptera may be relevant in Foothill stream, but not grassland streams where diversity and abundance of these groups is low).

Following are some key implications for the development of an AEH monitoring program on agricultural streams in Alberta.

- The AESA stream network offers a reasonable foundation in the sense that the 23 streams were selected from major ecoregions where agriculture is an important land use; streams were ranked according to agricultural intensity in their basins. There is a historical water quality database spanning a period of 8 to 13 years, depending on the stream. Surface water quality sampling was interrupted for all but 8 streams in 2008 and water quality sampling would need to resume.

- In order to define background conditions it would be necessary to expand the network. Considering that most of the network encompasses 4 ecoregions this could imply that a minimum of 80 (20 times 4$)$ streams would need to be selected and monitored to establish reference conditions. In some instances it may be possible to select streams that are 'minimally' impacted, but in others, such as grassland streams in central Alberta, or irrigation canals, the goal may be simply to define current baseline conditions. Establishing background conditions can require several years. Rosenberg et al. (1999) sampled 219 sites over a three year period to establish reference conditions for benthic invertebrate monitoring in the Fraser River catchment in British Columbia.

- Frequency and intensity of monitoring would be high initially (e.g., many streams over a period of 2 to 3 years). Later on monitoring could be reduced to a selection of representative streams (e.g., the established AESA network, every 5 years).

Periodic validation of a selection of reference sites would be useful to account for temporal variability. 
- Timing of sampling would be particularly critical in ephemeral streams of grassland and Parkland regions where late spring may be the only time with flowing water and established biological communities. Sampling in Foothills and Boreal plain streams could likely be postponed to early summer.

Although the financial commitment to such monitoring program is large, it is one of the realities of meaningful monitoring and reporting on aquatic ecosystem health. In this case, strong baseline information would be established and biocriteria could be developed to report periodically on aquatic ecosystem health of agricultural streams.

It is expected that the value of biomonitoring of agricultural streams would extend well beyond periodic reporting on aquatic ecosystem health of these streams.

- Establishing reference conditions for a variety of streams would be very helpful to assess effects of other land uses (e.g., forestry or urban development).

- Another major application of biomonitoring information could be the assessment of the effectiveness of beneficial management practices, including riparian conditions, on aquatic ecosystem health (e.g., if nutrient control measures on land are effective one would expect to see corresponding changes in epilithic algal and benthic invertebrate communities).

- As nutrient and diatom association datasets for Alberta streams and rivers are expanded, the possibility would exist to validate nutrient tolerance ranges (e.g., as defined by Potapova and Charles 2007) for the range of regional conditions in Alberta, thereby refining the value of diatoms in the assessment of stream eutrophication in Alberta.

- Preference ranges for other species groups could also be investigated with associated data sets (e.g., Carlisle et al. 2007 investigated the influence of water quality on benthic invertebrate distribution). 


\subsection{LITERATURE CITED}

\subsection{General Literature}

Alberta Environment. 2006. Aquatic Ecosystems Field Sampling Protocols.

Environmental Monitoring and Evaluation Branch, Environmental Assurance Division, Alberta Environment. 137 pp.

Anderson, A.-M. 1998. Water quality Monitoring program 1997. Annual Technical Report. Water quality monitoring of agricultural streams and lakes. Prepared for the AESA Water Quality Committee. Published by Alberta Agriculture, Food and Rural Development, Edmonton, AB.

Anderson, A.-M. 2000. Water quality Monitoring program 1998. Annual Technical Report. Water quality monitoring of agricultural streams and lakes. Prepared for the AESA Water Quality Committee. Published by Alberta Agriculture, Food and Rural Development, Edmonton, AB.

Anderson, A.-M., D.O. Trew, R.D. Neilson, N.D. MacAlpine, and R. Borg. 1998. Impacts of agriculture on surface water quality in Alberta. Part II. Provincial stream survey. Prepared for the CAESA Water Quality Committee. Published by AAFRD, Edmonton. 91 pp.

Anderson, A.-M., S.E. Cooke and N.MacAlpine 1999. Watershed selection for AESA stream monitoring program. Alberta Environmentally Sustainable Agriculture, Resource Monitoring, Water Quality. 159 p.

Barbour, M.T., J. Gerritsen, B.D. Snyder, and J.B. Stribling. 1999. Rapid Bioassessment Protocols for Use in Streams and Wadeable Rivers: Periphyteon, Benthic Macroinvertebrates and Fish, Second Edition. EPA 841-B-99-002. U.S. Environmental Protection Agency, Office of Water, Washington, D.C.

Carle, N. 2001. Water Quality Monitoring Program 2000. Annual Technical Report: Water Quality Monitoring of Small Streams in Agricultural Areas. Prepared for the AESA Water Quality Committee. Published by Alberta Agriculture, Food and Rural Development, Edmonton, AB.

Carlisle, D.M., M.R. Meador, S.R. Moulton II, P. M. Ruhl. 2007. Estimation and application of indicator values for common macroinvertebrate genera and families of the United States. Ecological Indicators 7: 22-33.

Davis, W.D. and T. P. Simon. Eds. 1995. Biological Assessment and Criteria tools for water resource planning and decision making. Lewis Publishers, Boca Raton. $415 \mathrm{p}$. 
Depoe, S. 2006a. Water Quality Monitoring Program 2004. Annual Technical Report: Water Quality Monitoring of Small Streams in Agricultural Areas. Prepared for the AESA Water Quality Committee. Published by Alberta Agriculture, Food and Rural Development (AAFRD), Edmonton, Alberta. 59 pp.

Depoe, S. 2006b. Water Quality Monitoring Program 2003. Annual Technical Report: Water Quality Monitoring of Small Streams in Agricultural Areas. Prepared for the AESA Water Quality Committee. Published by Alberta Agriculture, Food and Rural Development (AAFRD), Edmonton, Alberta. 55 pp.

Depoe, S. 2004. Water Quality Monitoring Program 2002. Annual Technical Report: Water Quality Monitoring of Small Streams in Agricultural Areas. Prepared for the AESA Water Quality Committee. Published by AAFRD, Edmonton, Alberta. $59 \mathrm{pp}$.

Depoe, S. and C.J.Westbrook, 2003. Water Quality Monitoring Program 2001. Annual Technical Report: Water Quality Monitoring of Small Streams in Agricultural Areas. Prepared for the AESA Water Quality Committee. Published by AAFRD, Edmonton, AB. 58 pp.

Elliott, J.M. 1977. Some methods for the statistical analysis of samples of benthic invertebrates. Freshwater Biological Association Scientific Publication No.25. $160 \mathrm{p}$.

Garnier, J. G. Billen and M. Coste. 1995. Seasonal succession of diatoms and Chlorophyceae in the drainage network of the Seine River: Observation and modeling. Limnol. Oceanogr. 40(4) 750-765.

Hilsenhoff, W.L. 1987. An improved biotic index of organic stream pollution. Great Lakes Entomol. 20(1): 31-36.

Hilsenhoff, W.L. 1988. Rapid field assessment of organic pollution with a family-level biotic index. J. N. Am. Benthol. Soc. 7(1): 65-68.

Hughes, R.M. 1995. Defining acceptable biological status by comparing with reference conditions. P31-47. In: Davis, W.D. and T. P. Simon. Eds. 1995. Biological Assessment and Criteria tools for water resource planning and decision making. Lewis Publishers, Boca Raton. 415p.

Jacques Whitford. 2005. Scope of work for the initiatl Assessment of aquatic ecosystem health in Alberta. Prepared for Alberta Environment, Edmonton. 47 p.

Jones, C. Somers, K.M. Craig, B. and Reynoldson, T. 2004. Ontario Benthos Biomonitoring Network protocol manual. Version 1. Ontario Minister of the Environment, Environment Canada, Acadia Centre for Estuarine Research, Ontario. 
Klemm, J. K.A. Bloksom, F.A. Fulk, A.T. Herlihy, R,M. Hughes, P.R. Kaufmann, D.V. Peck, J.L. Stoddard, W. T. Thoeny and M.B. Griffith. 2003. Development and evaluation of a macroinvertebrate biotic integrity index (MBII) for regionally assessing Mid-Atlantic Highlands streams. Environmental Management Vol. 31 (5): 656-669.

Lorenz K., S. Depoe and C. Phelan. 2008 (Draft). Assessment of Environmental Sustainability in Alberta's Agricultural Watershed Project. Water Resources Branch, Alberta Agriculture and Rural Development.

Mandaville, S.M. 2002. Benthic Macroinvertebrates in Freshwaters - Taxa Tolerance Values, Metrics, and Protocols. Project H-1. Soil and Water Conservation Society of Metro Halifax. 48 pp. + Appendices.

Marchant, R. 1989. A subsampler for samples of benthic invertebrates. Bulleting of the Australian Society of Limnology 12: 49-52.

National Water Quality Assessment (NAWQA) http://water.usgs.gov/nawqa/

North South Consultants Inc., Clearwater Consultants Inc. and Patricia Mitchell Environmental Consulting. 2007. Information synthesis and initial assessment of the status and health of aquatic ecosystems in Alberta: Surface water Quality, sediment quality and non-fish biota. Prepared for Alberta Environment, Edmonton, Alberta. http://environment.gov.ab.ca/info/library/7861.pdf

Omnerik, J.M. 1995. Ecoregions: a spatial Framework for environmental management. P 49- 62. In: Davis, W.D. and T. P. Simon. Eds. 1995. Biological Assessment and Criteria tools for water resource planning and decision making. Lewis Publishers, Boca Raton. 415p.

Potapova, M. 2005. Relationships of soft-bodied algae to water quality and habitat characteristics in U.S. rivers: Analysis of the National Water Quality Assessment (NAWQA) program data set. Report No 05-08. The Academy of Natural Sciences. Philadelphia. 28p.

Potapova, M. and D.F. Charles. 2007. Diatom metrics for monitoring eutrophication in rivers of the United States. Ecological Indicators 7: 48-70

Saffran, K.A.S., and A.-M. Anderson 2009 (Draft). An assessment of benthic invertebrates and epilithic algae at long-term river in the Bow River (Fall 2006). Alberta Environment. 157p

Soininen, J. 2004. Benthic diatom community structure in Boreal Streams. Distribution patterns along environmental and spatial gradients. Department of Biological and Environmental Sciences, University of Helsinki, Finland. 46 p. 
Stambaugh, C. J. Schieck and B. Eaton. 2006. Stream and wetland field data collection protocols: Alberta Biodiversity Monitoring program. Alberta Research Council, Vegreville, Alberta. 26p.

Steinberg, C. and S. Schiefele. 1988. Biological indication of trophy and pollution of running waters, Z Wasser-Abwasser Forsch 21: 227-234. Cited in Soininen, J. 2004

Stoddard, J.L. 2005. Use of ecological regions in aquatic assessments of ecological condition. Environmental Management 34(1): 61-70.

Sylvestre, S. 2004. Invertebrate Biomonitoring Field and Laboratory Manual for running water habitats. Enironment Canada, Pacific and Yukon Region.

Sylvestre, S. M. Fluegel and T. Tuominen. 2005. Benthic invertebrate assessment of streams in the Georgia Basin using the reference condition approach: Expansion of the Fraser River Monitoring Program. Environment Canada. Environmental Conservation Branch. Vancouver, British Columbia.

Tison, J., Y.-S. Park, M. Coste, J.G. Wasson, L. Ector. F. Rimet and F. Delmas. 2005. Typology of diatom communities and the influence of hydro-ecoregions: A study on the French hydrosystem scale. Water Research 39:3177-3188.

Wright, I.A., B.C. Chessman, P.G. Fairweather and L.J. Benson L.J. 1995. Measuring the impact of sewage effluent on the macroinvertebrate community of an upland stream: the effect of

Wrona, F.G., M.G. Culp and R.W. Davies. 1982. Macroinvertebrate subsampling: A simplified apparatus and approach. Can. J. Fish. Aquat. Sci. 39: 1051-1054.

Younos, T. (Ed.) 2002. Advances in water monitoring research. Lavoisier Librairie. 230p

\subsection{Taxonomic References: Benthic Invertebrates}

Alexander, C. P. \& G. W. Byers. 1981. Tipulidae. Pp. 153-190. IN: Manual of Nearctic Diptera, Vol 1. Research Branch, Agriculture Canada. Ottawa, ON.

Anonymous. 1997. A key to Cladocera (Crustacea) of British Columbia. Resources Inventory Committee. Victoria, BC.

Anonymous. 2003. Buglab Key to Western Baetidae Nymphs. www.usu.edu/buglab/projects/Western\%20Baetidae $\% 20$ Nymphs.pdf 
Anonymous. 2003. A image-based key to the zooplankton of the Northeast (USA). Version 2.0. Center for Freshwater Biology, Department of Zoology, University of New Hampshire. Dyrham: NH. http://cfb.unh.edu/CFBkey/index.html

Anonymous. 2005. The Mayflies of North America (Mayfly Central). www.entm.purdue/entomology/research/mayfly

Bednarik, A. F. \& W. P. McCafferty. 1979. Biosystematic revision of the genus Stenonema (Ephemeroptera: Heptageniidae). Government of Canada, Fisheries and Oceans Bulletin 201. Ottawa, ON.

Balcer, M. D., N. L. Korda \& S. I. Dodson. 1984. Zooplankton of the Great Lakes: A guide to the identification and ecology of the common crustacean species. University of Wisconsin Press: Madison, WI.

Baumann, R.W., A.R. Gaufin, and R.F. Surdick 1977. The stoneflies (Plecoptera) of the Rocky Mountains. Mem. Am. Ent. Soc. 31: 1-208.

Brigham, A. R., W. U. Brigham \& A. Gnilka (eds.). 1982. Aquatic insects and oligochaetes of North and South Carolina. Midwest Aquatic Enterprises: Mahomet, IL.

Brinkhurst, R. O. 1986. Guide to the freshwater aquatic microdile oligochaetes of North America. Department of Fisheries and Oceans: Ottawa, ON.

Burian, S. K. 2001. A revision of the genus Leptophlebia Westwood in North America (Ephemeroptera: Leptophlebiidae: Leptophlebiinae). Ohio Biological Survey 13(3). Columbus, $\mathrm{OH}$.

Cannings, R. A. \& K. M. Stuart. 1977. The dragonflies of British Columbia. British Columbia Provincial Museum-Handbook No. 35. Victoria, BC.

Clarke, A. H. 1981. The freshwater mollusks of Canada. National Museum of Natural Sciences. Ottawa, ON.

Clifford, H.C. 1991. Aquatic Invertebrates of Alberta. The University of Alberta Press. Edmonton, Alberta. 538 pp.

Davies, R. W. 1971. A key to the freshwater Hirudinoidea of Canada. J. Fish. Res. Bd. Canada. 28: 543-552.

Dillon, R. T., Jr. 2006. Key to freshwater gastropods of the Pacific Northwest. The Xerces Society: Pacific Northwest Taxonomic Workshop - Gastropoda. Missoula, MT. May 11-12, 2006.

Dillon, R., Jr. no date. Freshwater Mollusk Conservation Society Committee on the Status \& Distribution of Gastropods. www.cofc.edu/\%7Efwgna/fwgnahome.htm

Pilot Study to Evaluate the Practicality of Biological Monitoring of Small Agricultural Streams 32 in Alberta 
Edmunds, G. F., S. L. Jensen \& L. Brener. 1976. The mayflies of North America. University of Minnesota Press: Minneapolis, MN.

Edmondson, W. T. 1959. Fresh-water biology ( $2^{\text {nd }}$ ed.). John Wiley \& Sons, New York, NY.

Epler, J. H. 2001. Identification manual for the larval Chironomidae (Diptera) of North and South Carolina. A guide to the taxonomy of the midges of the southeastern United States, including Florida. Special Publication SJ2001-SP13. North Carolina Department of Environment and Natural Resources, Division of Water Quality, Raleigh, NC and St. Johns River Water Management District. Palatka, FL.

Jacobus, L. \& R. P. Randolph. 2005. Mayflies in Moscow: Northwest Ephemeroptera Nymphs. Northwest Biological Assessment Workshop. University of Idaho. Moscow, ID.

Havel, J. \& R. Rhodes 1998. The zooplankton project. Southwest Missouri State University. http://science.smsu.edu/zooplankton/

Kathman, R. D. \& R. O. Brinkhurst. 1999 (revised). Guide to the freshwater oligochaetes of North America. Aquatic Resources Center, College Grove, TN.

Klemm, D. J. 1985. A guide to the freshwater Annelida (Polychaeta, Naidid and Tubificid Oligochaeta, and Hirudinea of North America). Kendall/Hunt Publishing. Dubuque, IA.

Korinek, V. 1981. Diaphanosoma birgei n.sp. (Crustacea, Cladocera). A new species form America and its widely distributed subspecies Diaphanosoma birgei ssp. Lacustris n.ssp. Can. J. Zool. 59: 1115-1121.

Korinek, V. 1987. Revision of three species of the genus Diaphanosoma Fischer, 1850. Hydrobiologia 145: 35-45.

Larson, D. J.; Y. Alarie \& R. E. Roughly. 2000. Predaceous diving beetles (Coleoptera: Dytiscidae) of the Neartic region, with emphasis on the fauna of Canada and Alaska. NRC Press. Ottawa, ON.

Lowen, R. G. \& J. F. Flannagan. 1990. The nymph and male of Centroptilum infrequens MCD (Baetidae). IN: Mayflies and Stoneflies: I.C. Campbell (ed.). pp. 311-321. Kluwer Academic Publishers. Toronto, ON.

Lowen, R. G. \& J. F. Flannagan. 1991. Four Manitoba species of Centroptilum Eaton (Ephemeroptera: Baetidae) with remarks on the genus. IN: Overview and strategies of Ephemeroptera and Plecoptera. J. Alba-Tercedor \& A. SanchezOrtega (eds.). Sandhill Crane Press. Gainesville, FL. 
Lowen, R. G. \& J. F. Flannagan. 1992. Nymphs and imagoes of four North American species of Procloeon Bengtsson with description of a new species (Ephemeroptera: Baetidae). Can. Ent. 124: 97-108.

May, M.L. \& P.S. Corbet. 2001. Occurrence and taxonomic significance of a palpal spine in larvae of Enallagma and other genera (Odonata: Coenagrionidae). International J. Odonatology 4(1): 41-49.

Milligan, M. R. 1997. Identification manual for the aquatic oligochaeta of Florida. Volume I: Freshwater oligochaeta. Sarasota, FL.

McCafferty, W. P. \& R. D. Waltz. 1990. Revisionary synopsis of the Baetidae (Ephemeroptera) of North and Middle America. Trans. Am. Entomol. Soc. 116(4): 769-799.

Merritt, R. W. \& K. W. Cummins (eds.) 1996. An introduction to the aquatic insects of North America $\left(3^{\text {rd }}\right.$ ed. $)$. Kendall/Hunt Publishing. Dubuque, IA.

Morihara, D. K. \& W. P. McCafferty. 1979. The Baetis larvae of North America (Ephemeroptera: Baetidae). Trans. Am. Entomol. Soc. 105:139-221.

Nimmo, A. P. 1965. A new species of Psychoglypha Ross from western Canada, with notes on several other species of Limnephilidae (Trichoptera). Can. J. Zool. 43: 781-787.

Pescador, M. L. \& A. K. Rasmussen. 1995. Identification manual for the caddisfly (Trichoptera) of Florida. Department of Environmental Protection, Division of Water Facilities. Tallahassee, FL.

Poirrier, M. A. \& Y. M. Arceneaux. 1972. Studies on southern Sisyridae (Spongillaflies) with a key to the third-instar larvae and additional sponge-host records. Amer. Midland Nat. 88(2): 455-458.

Pupedis, R. J. 1980. Generic differences among new world Spongilla-fly larvae and a description of the female of Climacia striata (Neuroptera: Sisyridae). Psyche 87: 305-314.

Ross, H. H. 1944. The caddisflies, of Trichoptera of Illinois. Illinois Natural History Bulletin 23(1). Urbana, IL.

Sawyer, R. T. 1972. North American freshwater leeches, exclusive of the Pisciolidae, with a key to all species. University of Illinois Press. Urbana, IL.

Smirnov, N. N. 1971. Fauna of the U.S.S.R. crustacean, Vol. 1(2): Chydoridae. Israel Program for Scientific Translation. Jerusalem, Israel. 
Smith, D. G. 2001. Pennak's freshwater invertebrates of the United States $\left(4^{\text {th }}\right.$ ed. $)$. New York: John Wiley and Sons, Inc. New York, NY.

Stephenson, J. 1972. The oligochaeta. Wheldon \& Wesley Ltd. New York, NY.

Stewart, K. W. \& B. P. Stark. 2002. Nymphs of North American Stonefly genera (Plecoptera) $\left(2^{\text {nd }}\right.$ ed.). The Caddis Press. Columbus, $\mathrm{OH}$.

Steyskal, G. C. \& L. V. Knutson. 1981. Empididae. Pp. 607-624. IN: Manual of Nearctic Diptera, Vol 1. Research Branch, Agriculture Canada. Ottawa, ON.

Tennessen, K. 2007. Odonata larvae of the Pacific Northwest (An identification Manual). Watutoma, WI.

Teskey, H. J. 1981. Key to the Families-Larvae. Pp. 125-147. IN: Manual of Nearctic Diptera, Vol 1. Research Branch, Agriculture Canada. Ottawa, ON.

Thorp, J. H. \& A. P. Covich. 2001. Ecology and classification of North American freshwater invertebrates ( $2^{\text {nd }}$ ed.). Academic Press. San Diego, CA.

Usinger, R. L. (ed.) 1956. Aquatic insects of California. Berkeley: University of California Press. Berkeley, CA.

Waltz, R. D. \& W. P. McCafferty. 1987. New genera of Baetidae for some Nearctic species previously included in Baetis Leach (Ephemeroptera). Ann. Entomol. Soc. Am. 80(5): 667-670.

Wiersema, N. A. 1999. Two new species of Procloeon (Ephemeroptera: Baetidae) from Texas. Ent. News 110(1): 27-35.

Wiederholm, T. (ed.). 1983. Chironomidae of the Holarctic region: Keys and diagnoses. Part 1: Larvae. Ent. Scandinavica Supplement 19.

Wiggins, G. B. 1960. A preliminary systematic study of the North American larvae of the caddisfly family Phryganeidae (Trichoptera). Can. J. Zool. 38: 1153-1170.

Wiggins, G. B. 1996. Larvae of the North American Caddisfly genera (Trichoptera) $\left(2^{\text {nd }}\right.$ ed.). University of Toronto Press. Toronto, ON.

Zimmerman, J. R. 1981. A revision of the Colymbetes of North America (Dytisicidae). The Coleopterists Bul. 35(1): 1-52.

\subsection{Taxonomic References: Algae}

Anton, A. and H. C. Duthie. 1981. Use of cluster analysis in the systematics of the algal genus Cryptomonas. Can J. Bot. 59: 992-1002. 
Bahls, L. 2004. Northwest Diatoms: A photographic catalogue of species in the Montana Diatom Collection, with ecological optima, associates, and northern distribution records for the nine northwestern United States.

Camburn, K. and D. F. Charles. 2000. Diatoms of low-alkalinity lakes in the northeastern United States. The Academy of Natural Sciences of Philadelphia. $152 \mathrm{pp}$.

Cumming, B.F., Wilson, S.E. and J.P. Smol. 1995. Diatoms from British Columbia (Canada) lakes and their relationship to salinity, nutrients and other limnological variables. Bibliotheca Diatomologica. Band 31. J. Cramer, Berlin, Stuttgart. 207 pp.

Entwisle, T. J., Skinner, S. Lewis, S. H. and H.J. Foard. 2007. Algae of Australia: Batrachospermales, Thoreales, Odeogoniales and Zygnemacae. ABRS, Caberra; CSIRO Publishing, Melbourne. $191 \mathrm{pp}$.

Fallu, M.-A, N. Allaire and R. Pienitz. 2000 . Freshwater Diatoms from northern Québec and Labrador (Canada). Bibliotheca Diatomologica. Band 45. J. Cramer, Berlin, Stuttgart. $200 \mathrm{pp}$.

Findlay, D. L. and H. J. Kling. 1976. A species list and pictorial reference to the phytoplankton of central and northern Canada. Fisheries and Environment Canada, Fisheries and Marine Service, Manuscript Report No. 1503. 619 pp.

Hamilton, P. 1990 . The revised edition of a computerized counter for plankton, periphyton and sediment diatom analysis. Hydrobiologia. 194: 23-30.

Huber-Pestalozzi, G. 1961. Das phytoplankton des Süßwassers. Systematik und Biologie. 5 Teil, Chlorophyceae (Grünalgen), Ordnung: Volvocales Die Binnengewäser (Band XVI). - E. Schweizerbart'sche Verlagsbuchhandlung (Nägele u Obermiller), Stuttgart. 728 pp.

Huber-Pestalozzi, G. 1972. Das phytoplankton des Süßwassers. Systematik und Biologie. 6 Teil, Chlorophyceae (Grünalgen), Ordnung: Tetrasporales von B. Fott. Die Binnengewäser (Band XVI). - E. Schweizerbart'sche Verlagsbuchhandlung (Nägele u Obermiller), Stuttgart. $47 \mathrm{pp}$

Huber-Pestalozzi, G. 1982. Das phytoplankton des Süßwassers. Systematik und Biologie. 8 Teil, 1 Halfte. Conjugatophyceae Zygnematales und Desmidiales von Kurt Förster, Pfronten/Allgäu Die Binnengewäser (Band XVI). - E.

Schweizerbart'sche Verlagsbuchhandlung (Nägele u Obermiller), Stuttgart. 543 pp.

Huber-Pestalozzi, G. 1983. Das phytoplankton des Süßwassers. Systematik und Biologie. 7 Teil, 1 Halfte. Chlorophyceae (Grünalgen), Ordnung: Chlorococcales 
von J. Komarek und B. Fott. Die Binnengewäser (Band XVI). - E.

Schweizerbart'sche Verlagsbuchhandlung (Nägele u Obermiller), Stuttgart. 1044 pp.

Jüttner, I., S. Sharma, B.M. Dahal, S.J. Omerod, P.J. Chimonides and E.J. Cox. 2003. Diatoms as indicators of stream quality in the Kathmandu Valley and Middle Hills of Nepal and India. Freshwater Biol. 48: 2065-2084.

Komàrek J. and K. Anagnostidis. 1998. Cyanoprokaryota. 1. Teil: Chroococcales. In: Ettl, H. et al. (eds.): Süswasserflora von Mitteleuropa. Begründet von A. Pascher. Band 19/1. Gustav Fischer. 584 pp.

Komàrek J. and K. Anagnostidis. 2005. Cyanoprokaryota. 2. Teil: Oscillatoriales. Süswasserflora von Mitteleuropa. Founded by A. Pascher. Edited by Burkhard Büdel, Lothar Krientiz, Georg Gärtner and Michael Schagerl. Volume 19/1. Elsevier Spektrum Akademischer Verlag. 759 pp.

Krammer, K. and H. Lange-Bertalot. 1986. Bacillariophyceae. 1. Teil: Naviculaceae. In: Ettl, H. et al. (eds.): Süswasserflora von Mitteleuropa. Begründet von A. Pascher. Band 2/1. Stuttgart-Jena. 876 pp.

Krammer, K. and H. Lange-Bertalot. 1988. Bacillariophyceae. 2 Teil: Bacillariaceae, Epithemiaceae, Surirellaceae. In: Ettl, H. et al. (eds.): Süswasserflora von Mitteleuropa. Begründet von A. Pascher Band 2/2. Stuttgart-Jena. 596 pp.

Krammer, K. and H. Lange-Bertalot. 1991a. Bacillariophyceae. 3 Teil: Centrales, Fragilariaceae, Eunotiaceae. Unter Mitarbet von H. Häkansson \& M. Nörpel. In: In: Ettl, H. et al. (eds.): Süswasserflora von Mitteleuropa. Begründet von A. Pascher Band 2/3. Stuttgart-Jena. 576 pp.

Krammer, K. and H. Lange-Bertalot. 1991b. Bacillariophyceae. 4 Teil: Achnanthaceae Kritische Ergänzungen zu Navicula (Lineolatae) und Gomphonema. In: Ettl, H. et al. (eds.): Süswasserflora von Mitteleuropa. Band 2/4. Stuttgart-Jena. 437 pp.

Lund, J. W. G., Kippling, C. and E. D. le Cren. 1958. The inverted microscope method of estimating algal numbers and the statistical basis for the estimation by counting. Hydrobiol. 11: 144-170.

Patrick, R. and C.W. Reimer. 1966. The Diatoms of the United States Exclusive of Alaska and Hawaii. Vol. 1. The Academy of Natural Sciences of Philadelphia. $688 \mathrm{pp}$.

Patrick, R. and C.W. Reimer. 1975. The Diatoms of the United States Exclusive of Alaska and Hawaii. Vol. 2, Part 1. The Academy of Natural Sciences of Philadelphia. 213 pp. 
Prescott, G. W. 1982. Algae of the western Great Lakes. Otto Koeltz Science Publishers. 977 pp.

Reavie, E.D. and J.P. Smol. 1998. Freshwater diatoms from the St. Lawrence River. Bibliotheca Diatomologica. Band 41. J. Cramer, Berlin, Stuttgart. 136 pp.

Rott, E. 1981. Some results from phytoplankton counting inter-calibrations. Schweiz Z. Hydrol. 24: 15-24.

Siver, P.A. and H. Kling. 1997. Morphological observations of Aulacoseira using scanning microscopy. Can. J. Bot. 75: 1807-1835.

Siver, P.A., P.B. Hamilton, K. Stachura-Suchoples and J.P. Kociolek. 2005. Diatoms of North America: The Freshwater Flora of Cape Cod, Massachusetts, USA. Iconographia Diatomologica. $463 \mathrm{pp}$.

Starmach, K. 1985. Chrysophyceae und Haptophyceae. In: Ettl, H. et al. (eds.): Süswasserflora von Mitteleuropa. Begründet von A. Pascher Band 1. VEB Gustav Fischer Verlag, Jena. 515 pp.

Tikkanen, T. 1986 . Kasviplantonopas. Suomen Luonnosuojelun Tuki Oy. 278 pp.

Wehr, J. D. and R. G. Sheath. 2003. Freshwater Algae of North America. Academic Press. $918 \mathrm{pp}$.

Whitford, L. A. and G. J. Schumacher. 1984. A manual of Freshwater Algae. Sparks Press, N.C. 337 pp. 


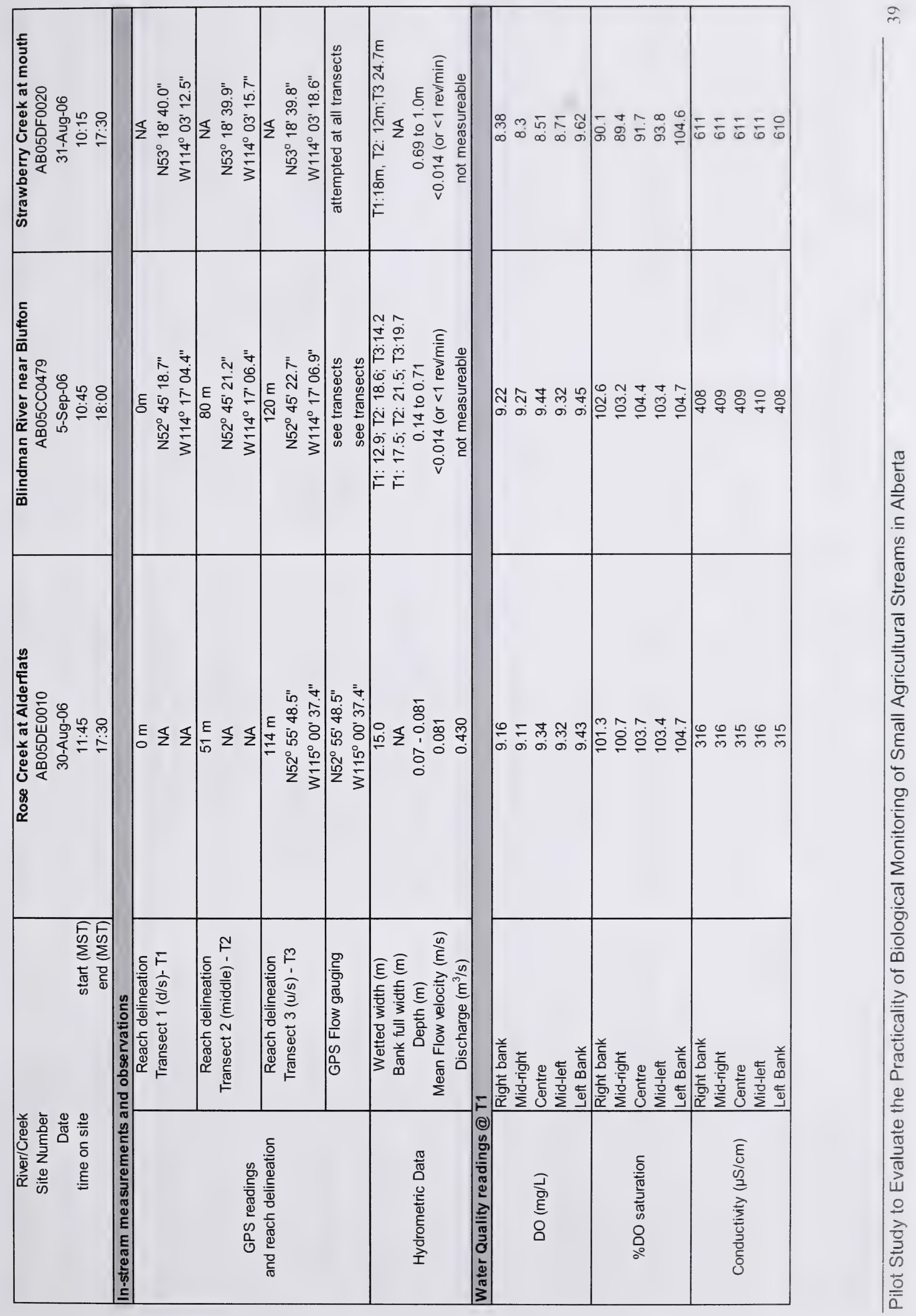




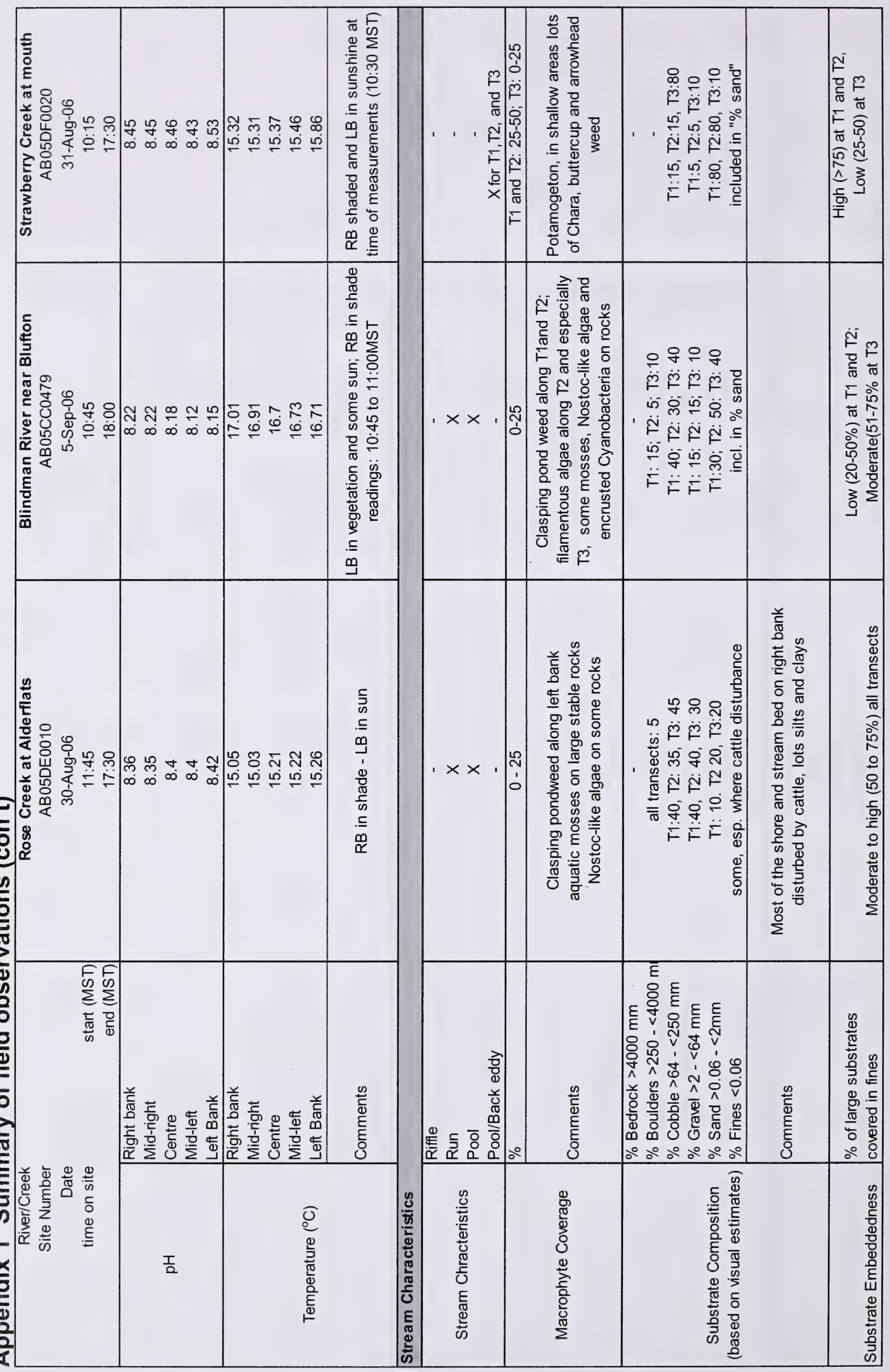




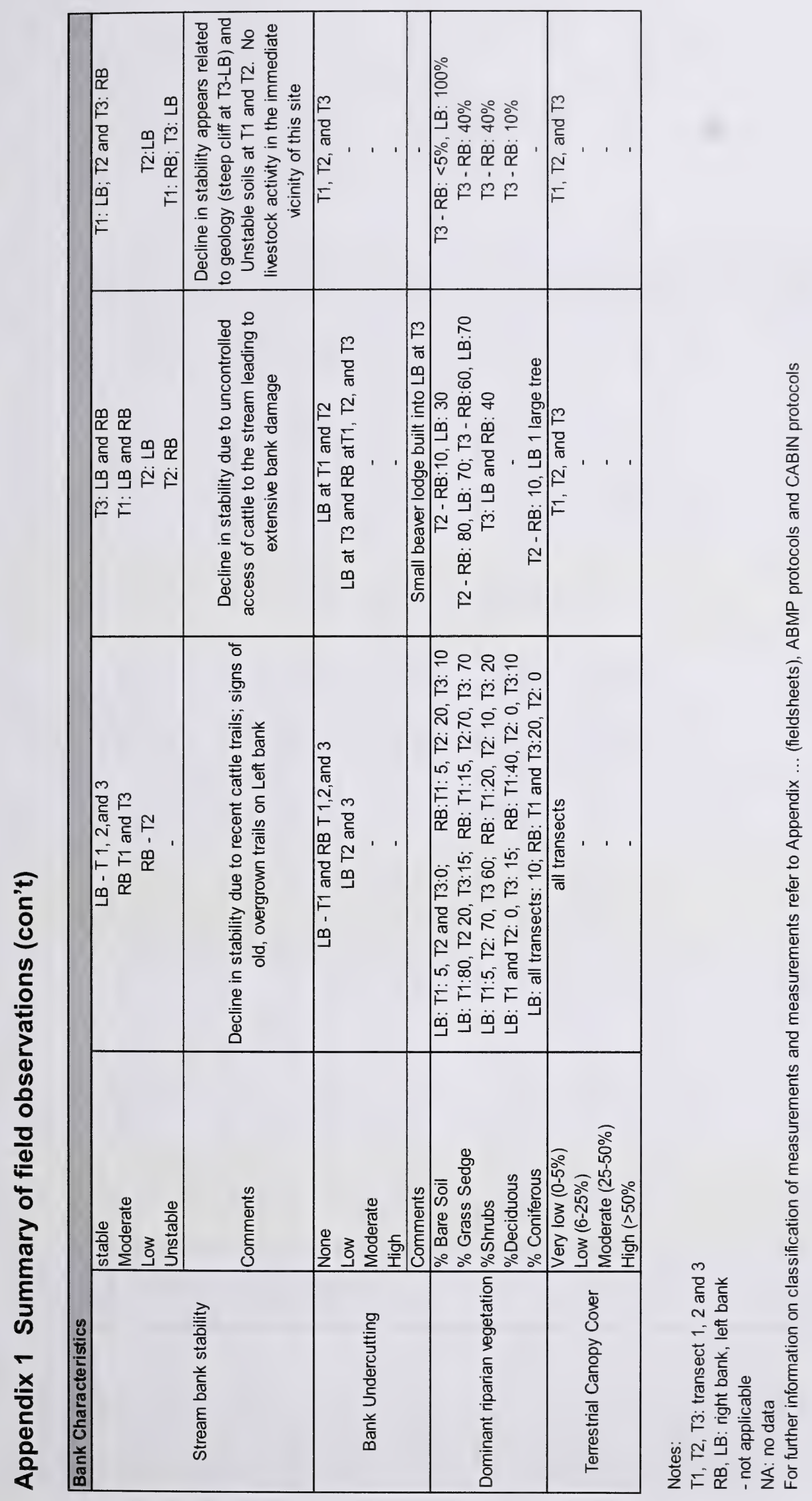




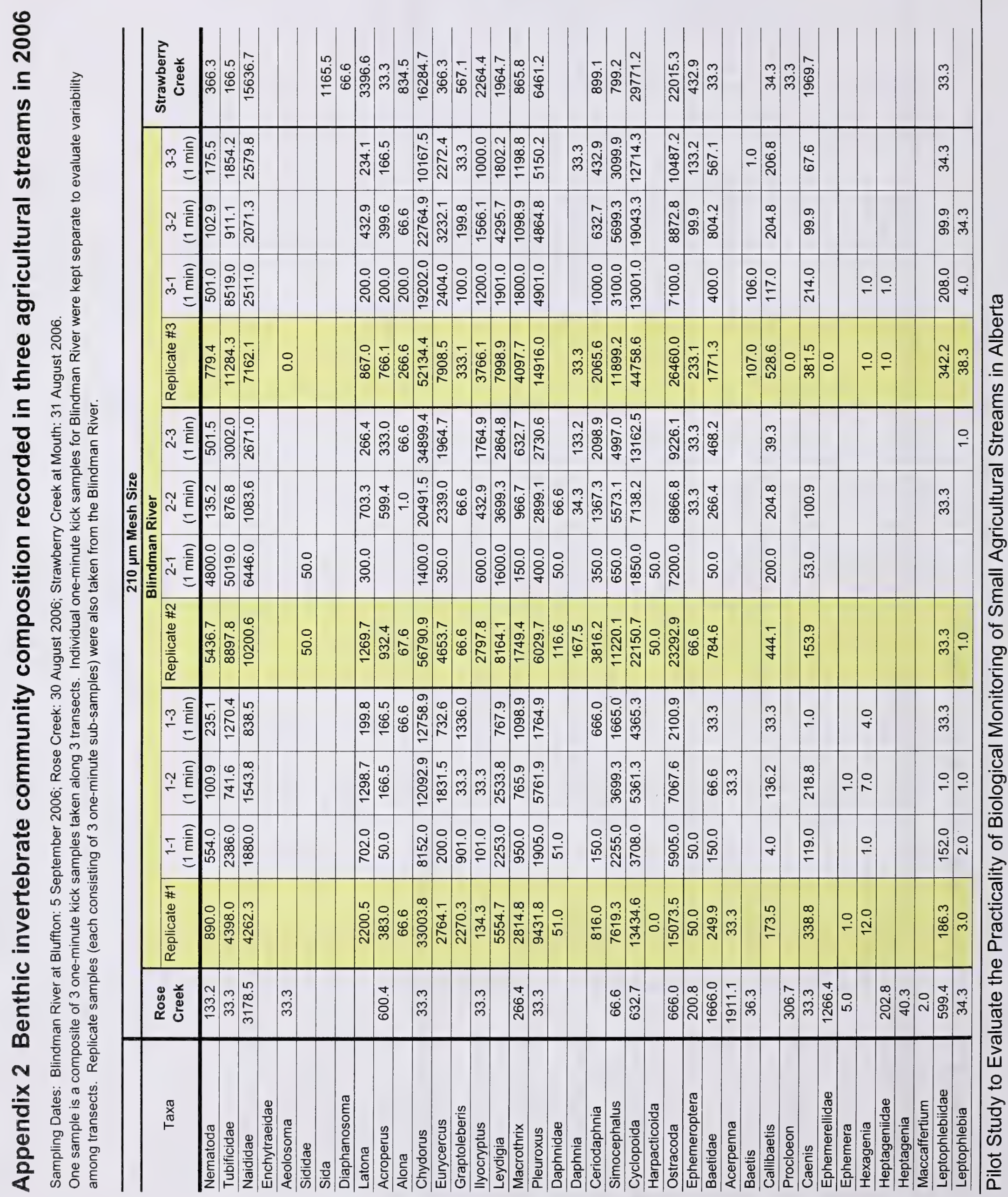




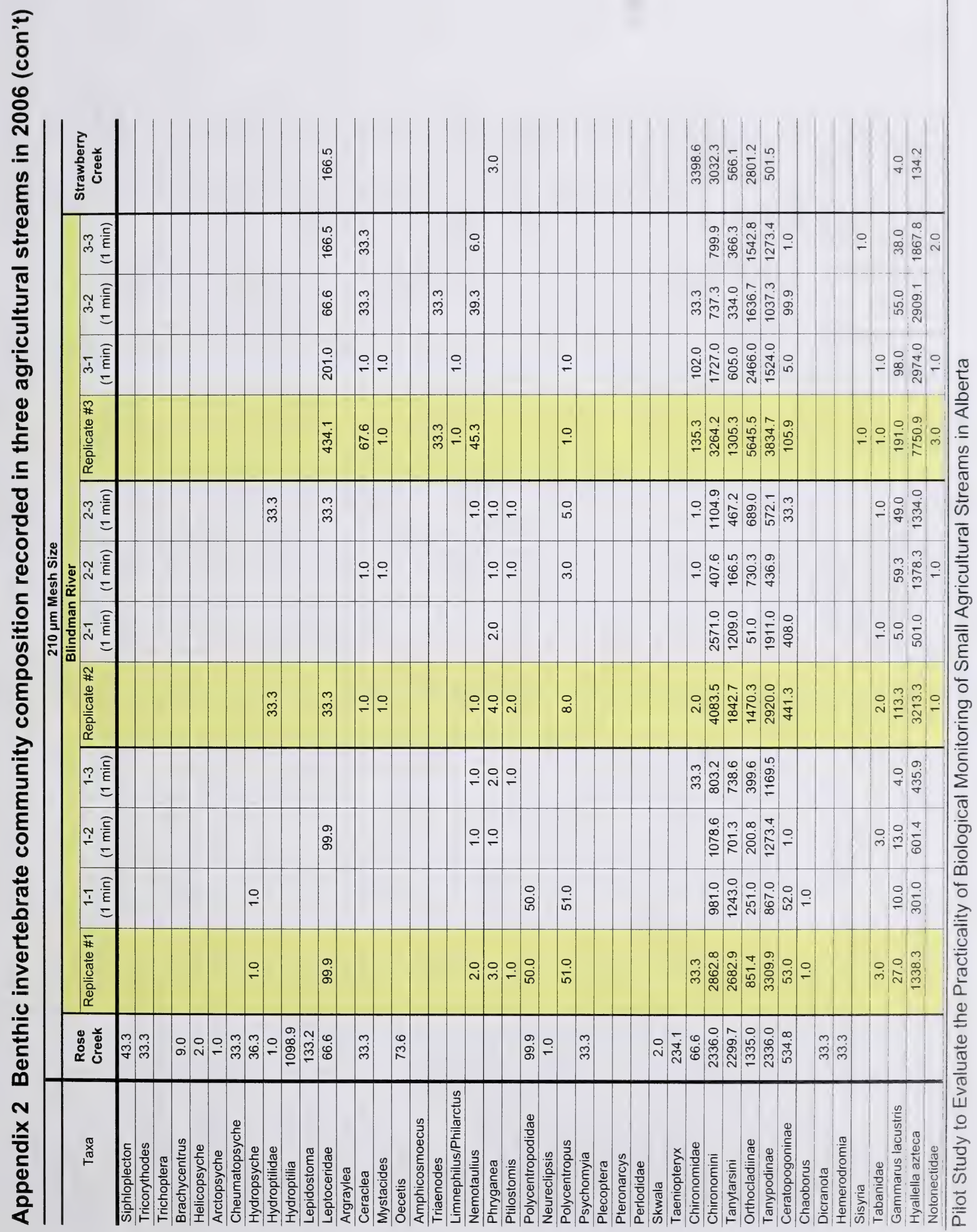




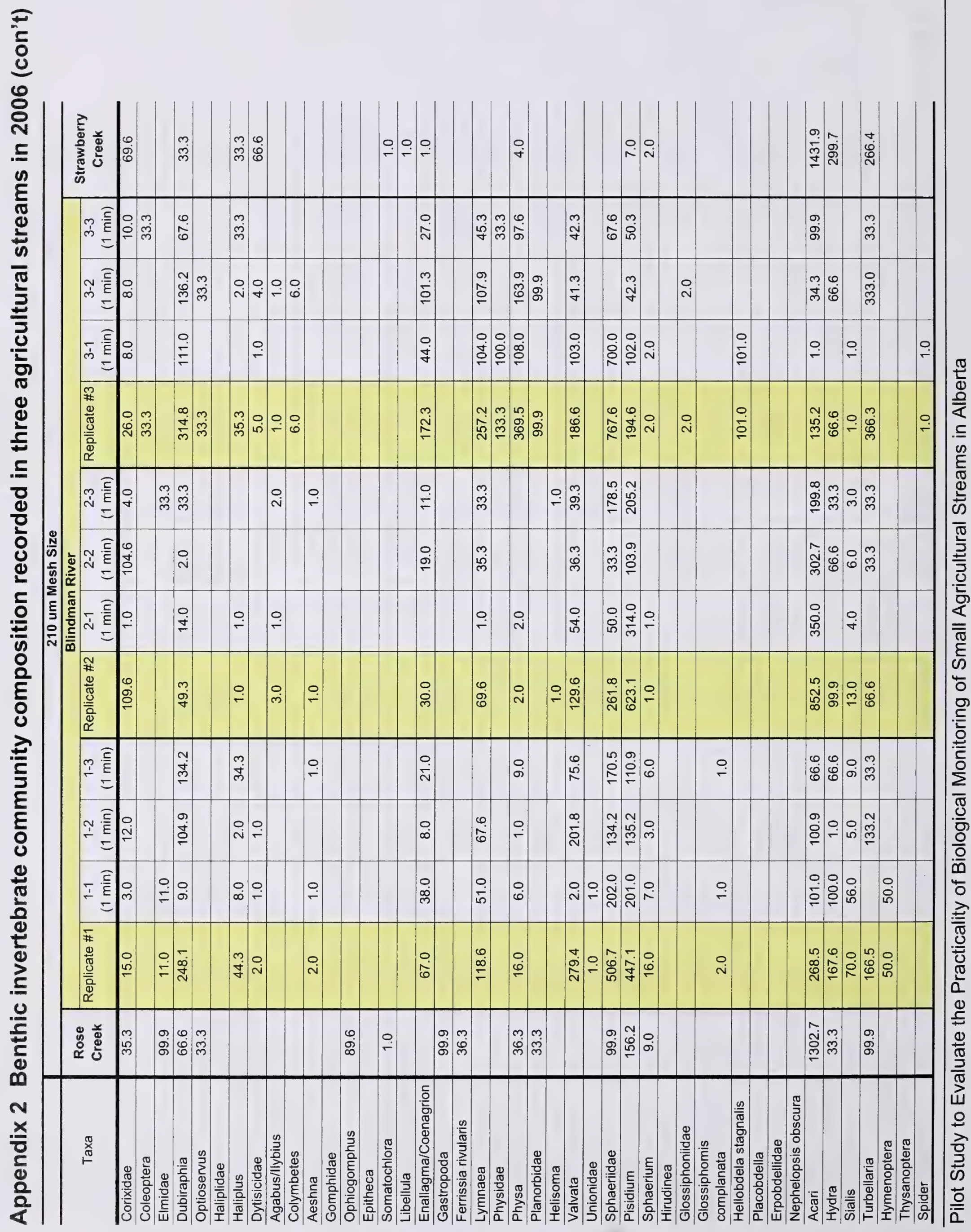




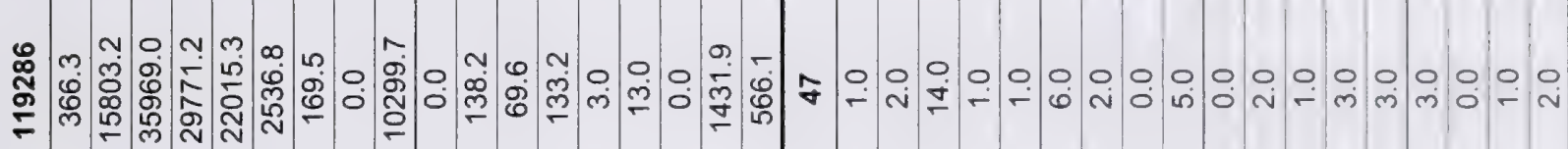

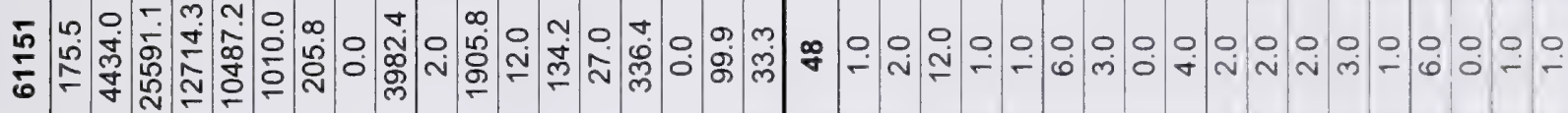

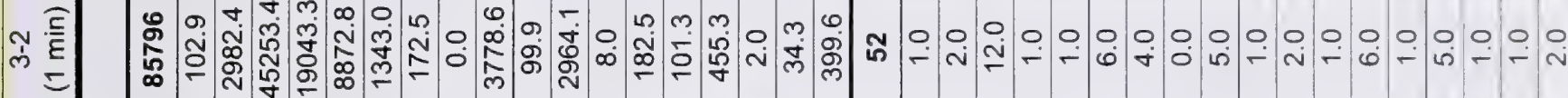

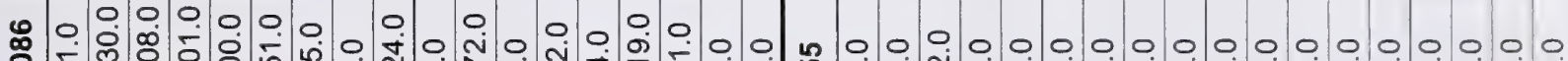

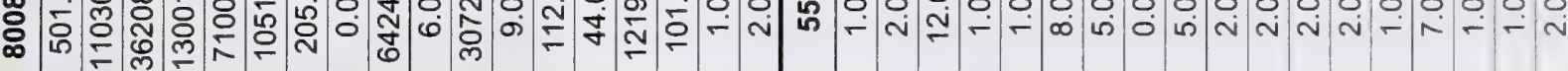

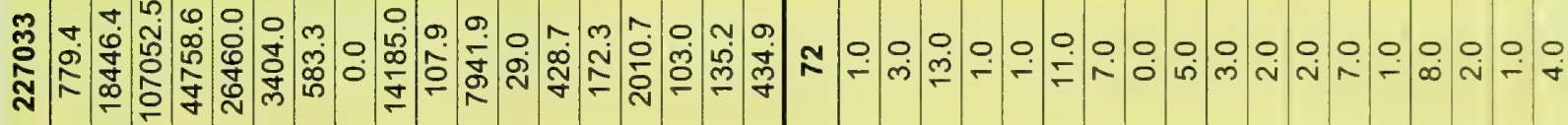

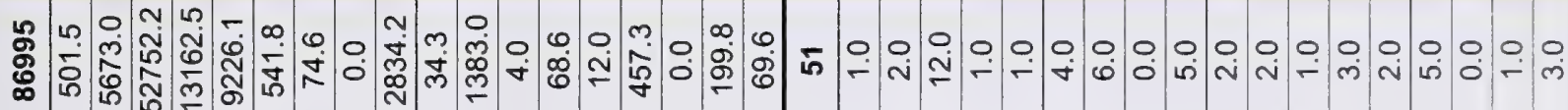
욱 N

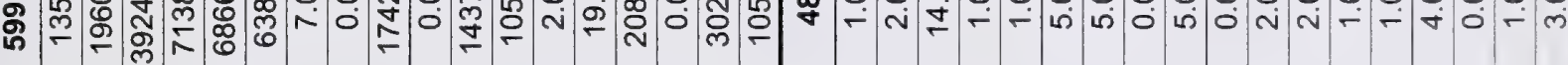
突

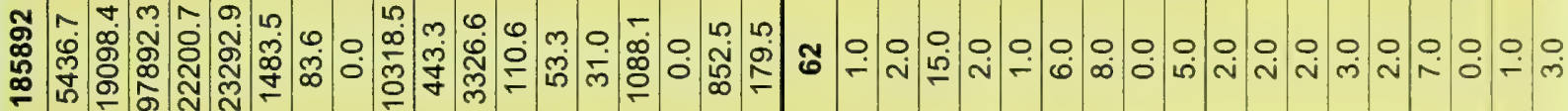

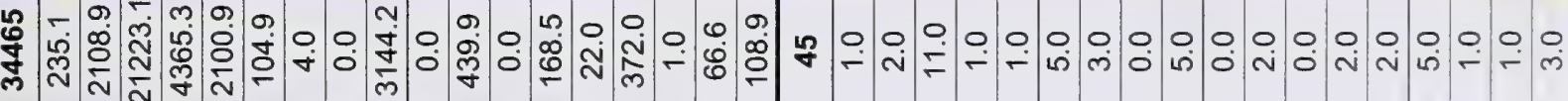

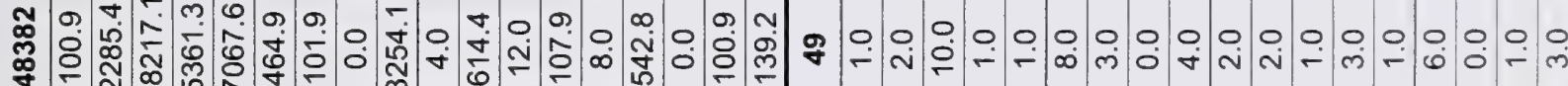

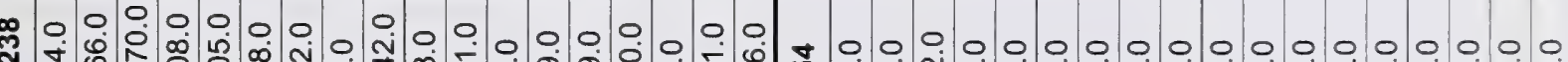

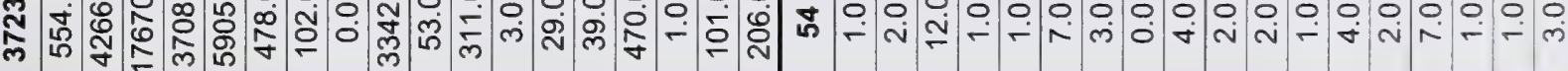

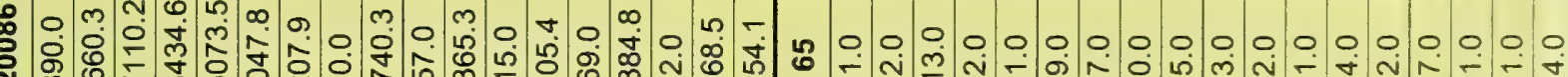

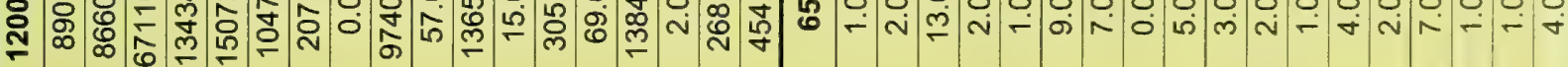

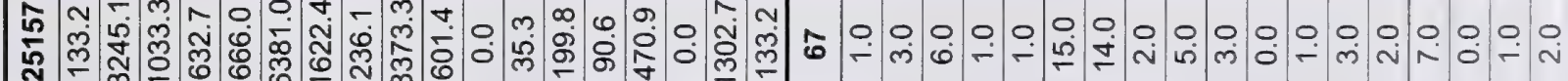




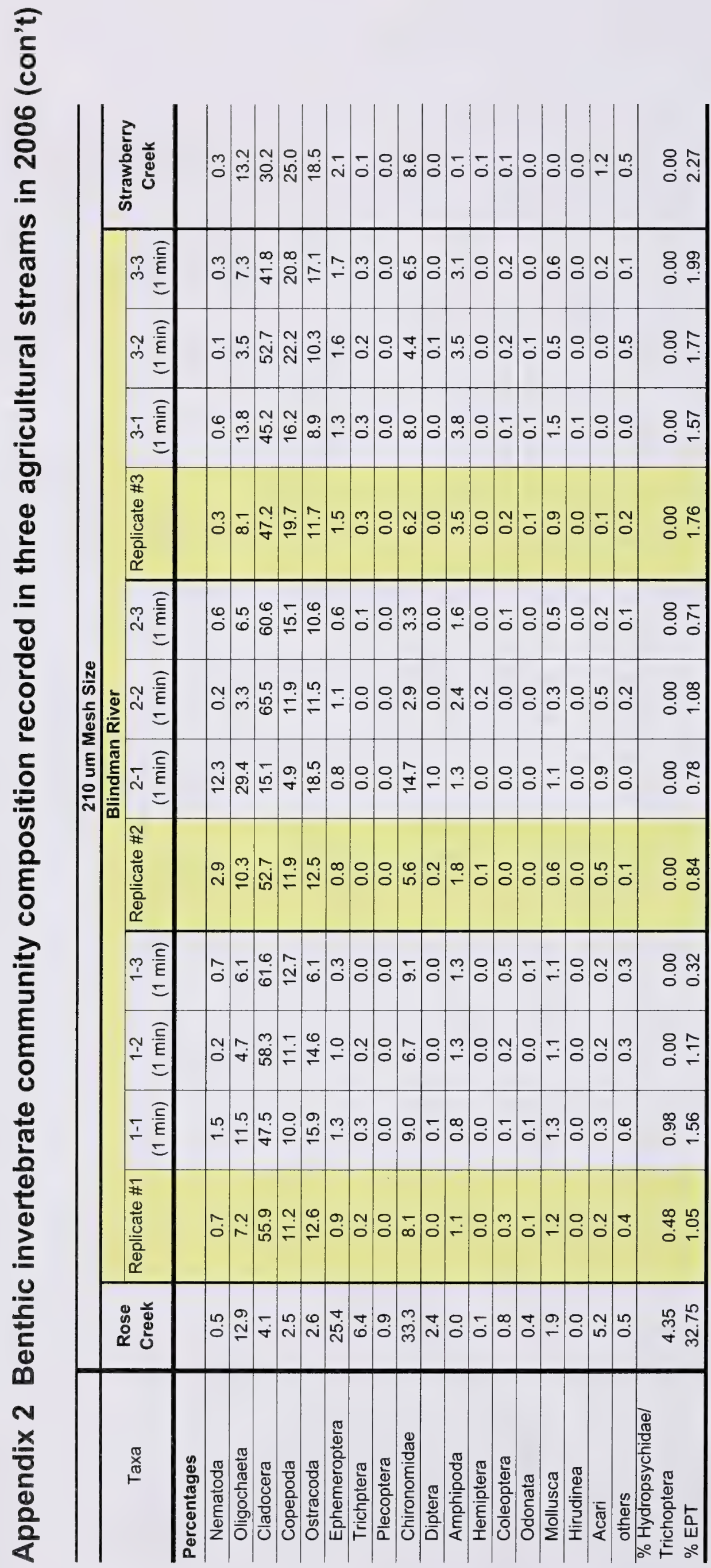




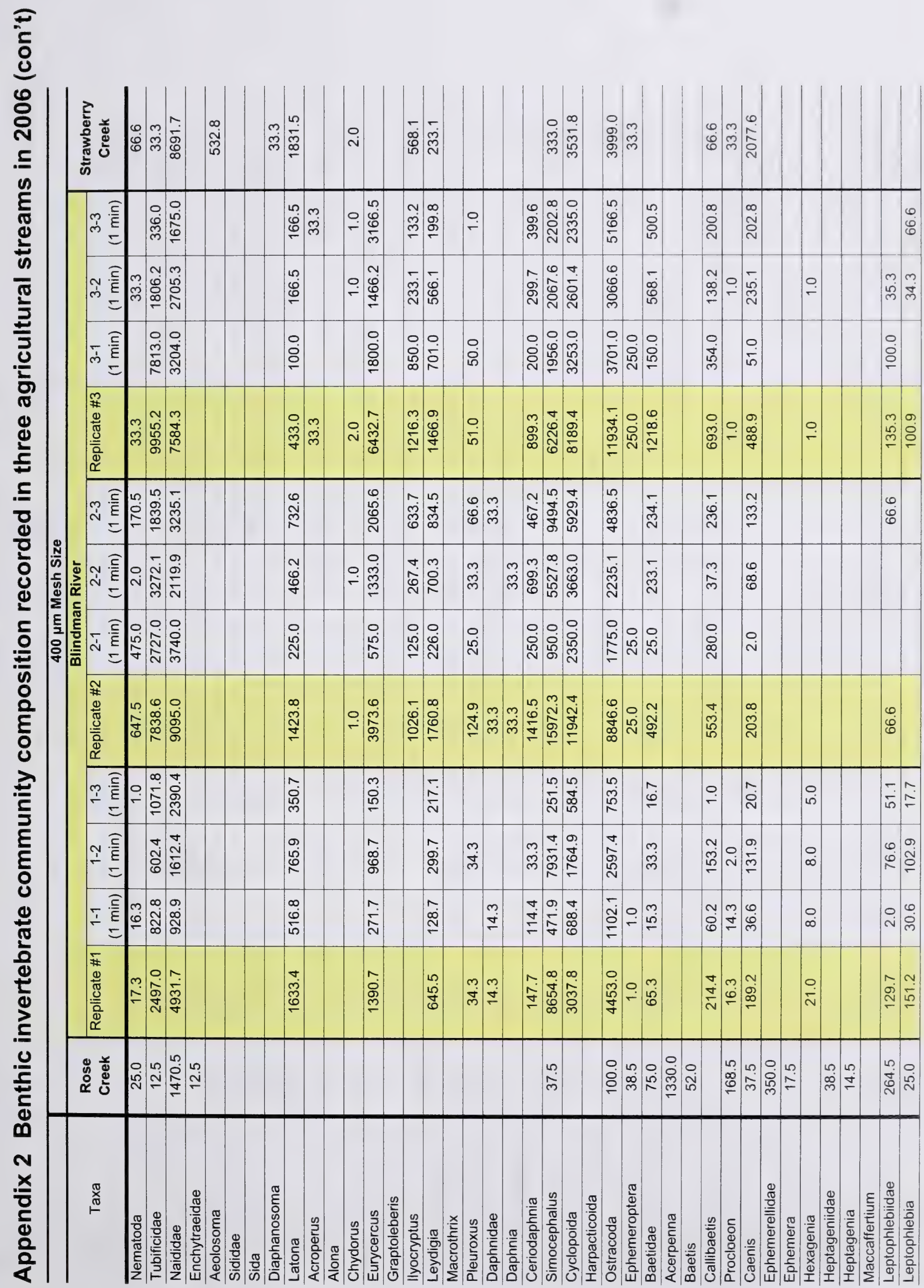


동

$\frac{2}{8}$

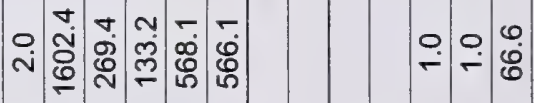
क

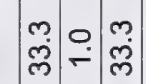

$\stackrel{\circ}{\dot{m}} \stackrel{\circ}{-} \stackrel{0}{-}$

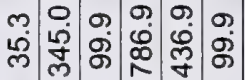

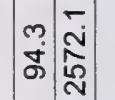

존

हิ

m.

ले

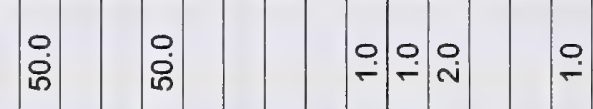

ஸื่

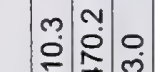

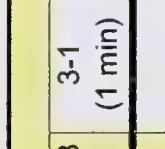

오

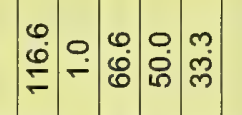

일일

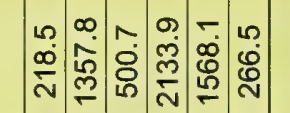

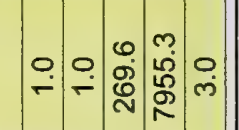

:

이웅

m.

일

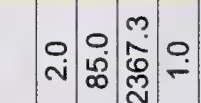

.

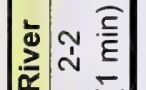

m్m

ㅇ. $\quad$ i $\quad \dot{0}$

岕:

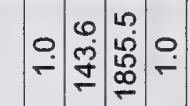

离

ธิ

ํㅗำ

$\stackrel{\circ}{-} \quad \stackrel{0}{-}$

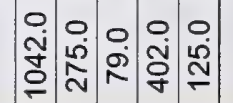

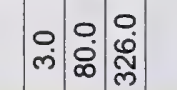

g̊.

인

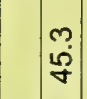

究

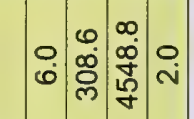

$\frac{x}{m \text { 들 }}$

$5+2000$

它

ヘ.

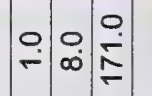

昰高

$\stackrel{\circ}{-} \underset{m}{m}$

…

$\underset{\substack{\infty \\ \infty}}{\infty}$

$\stackrel{\circ}{-} \stackrel{\circ}{-}$

$\stackrel{\circ}{-}$

$\stackrel{\circ}{-} \frac{9}{6}$

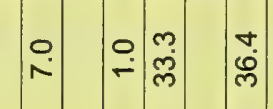

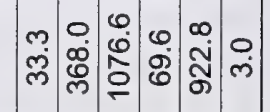

玄产

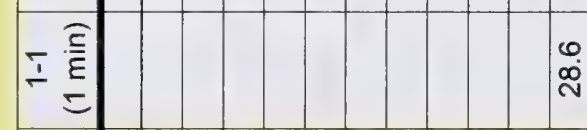

$\stackrel{\circ}{-}$

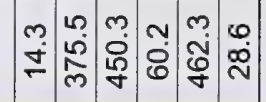

월

ֻٕ

लె户

$\stackrel{\circ}{-}$

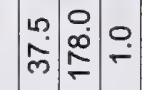

号

은. $\quad \begin{gathered}\infty \\ \infty \\ \infty\end{gathered}$

m.ं.-

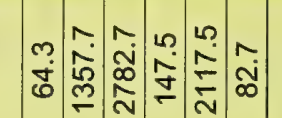

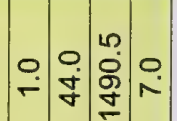

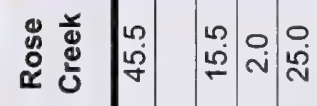

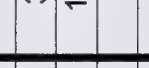

登

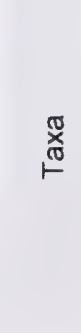
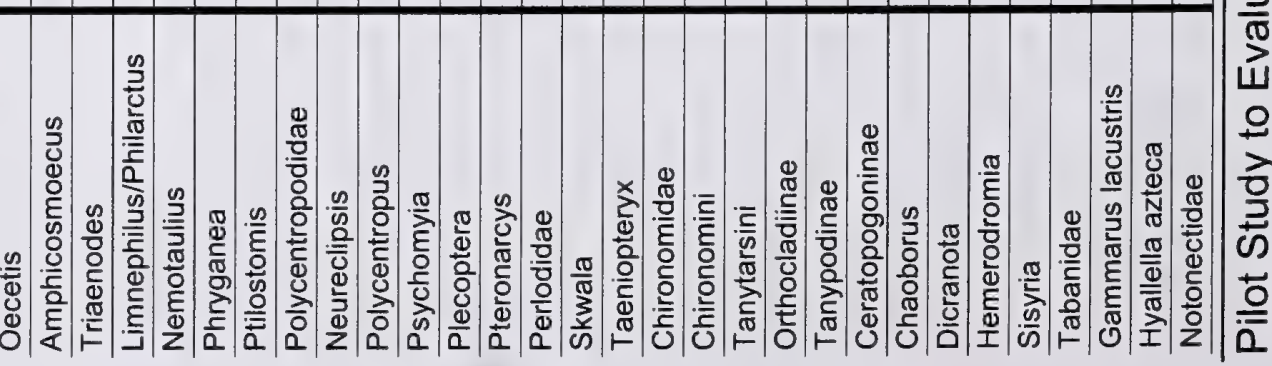


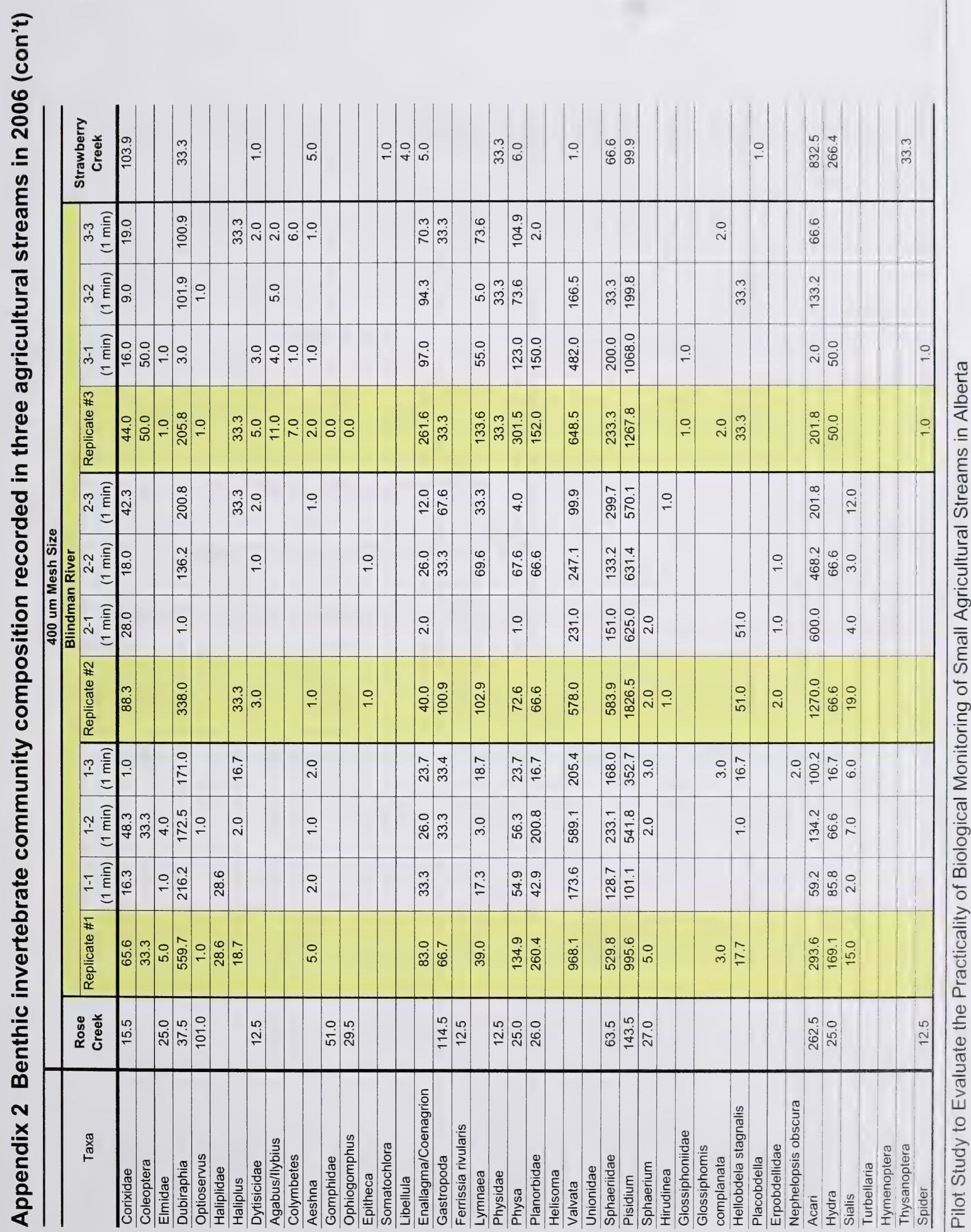


总

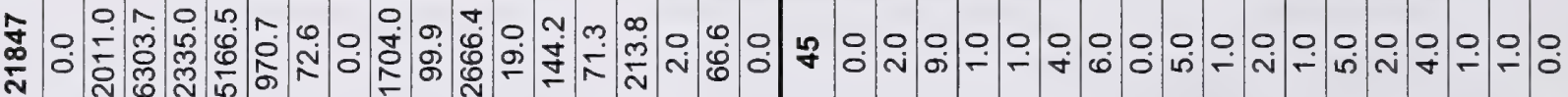
N

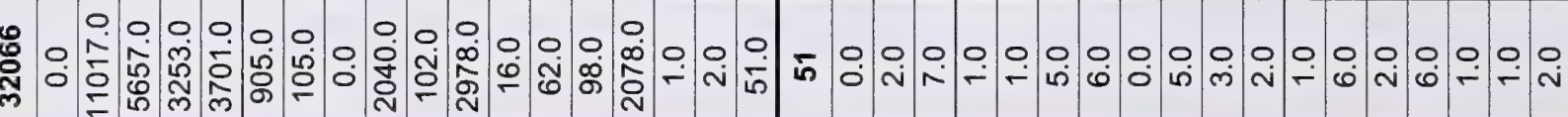

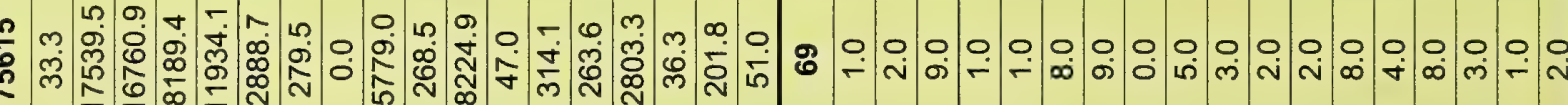
no

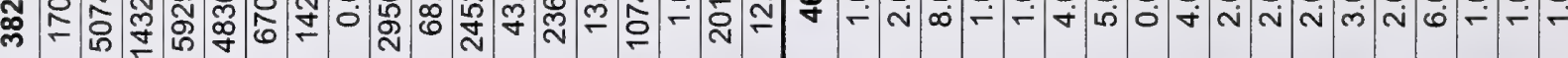

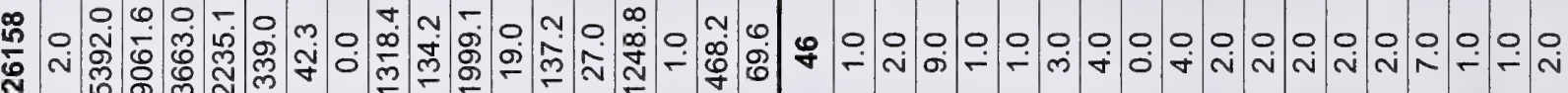

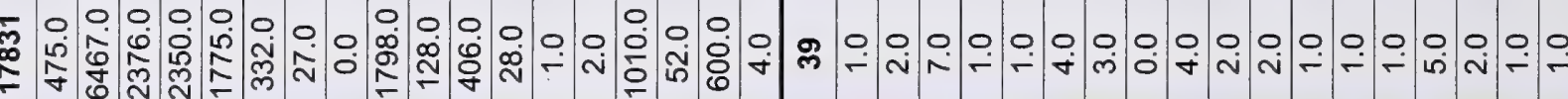

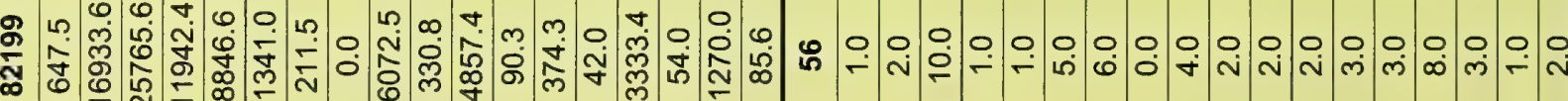

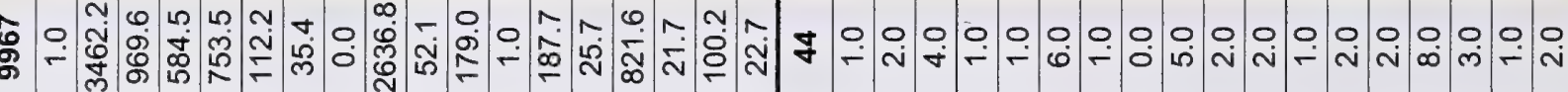

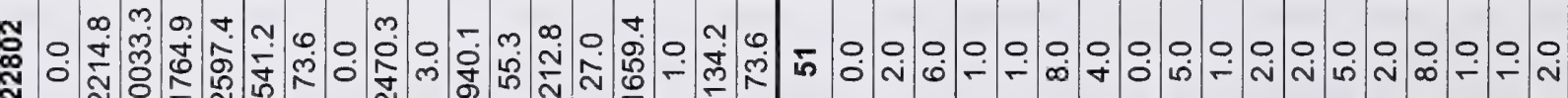

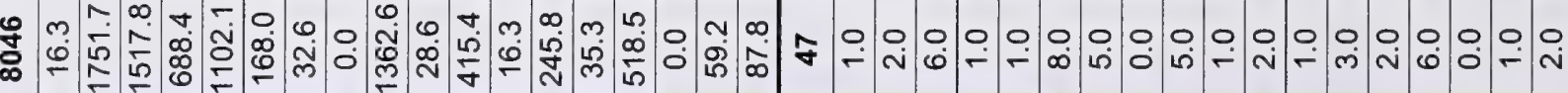

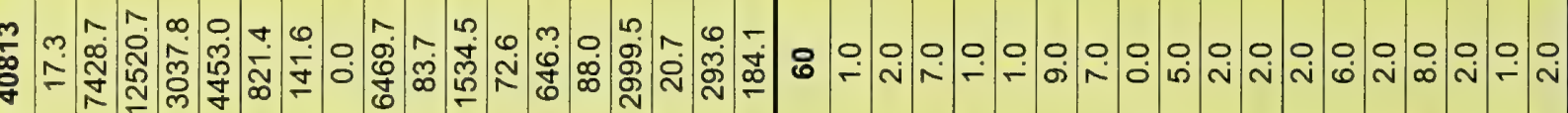

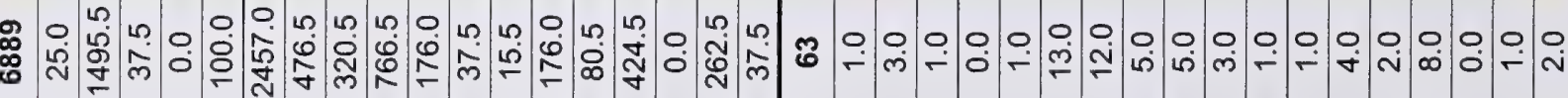




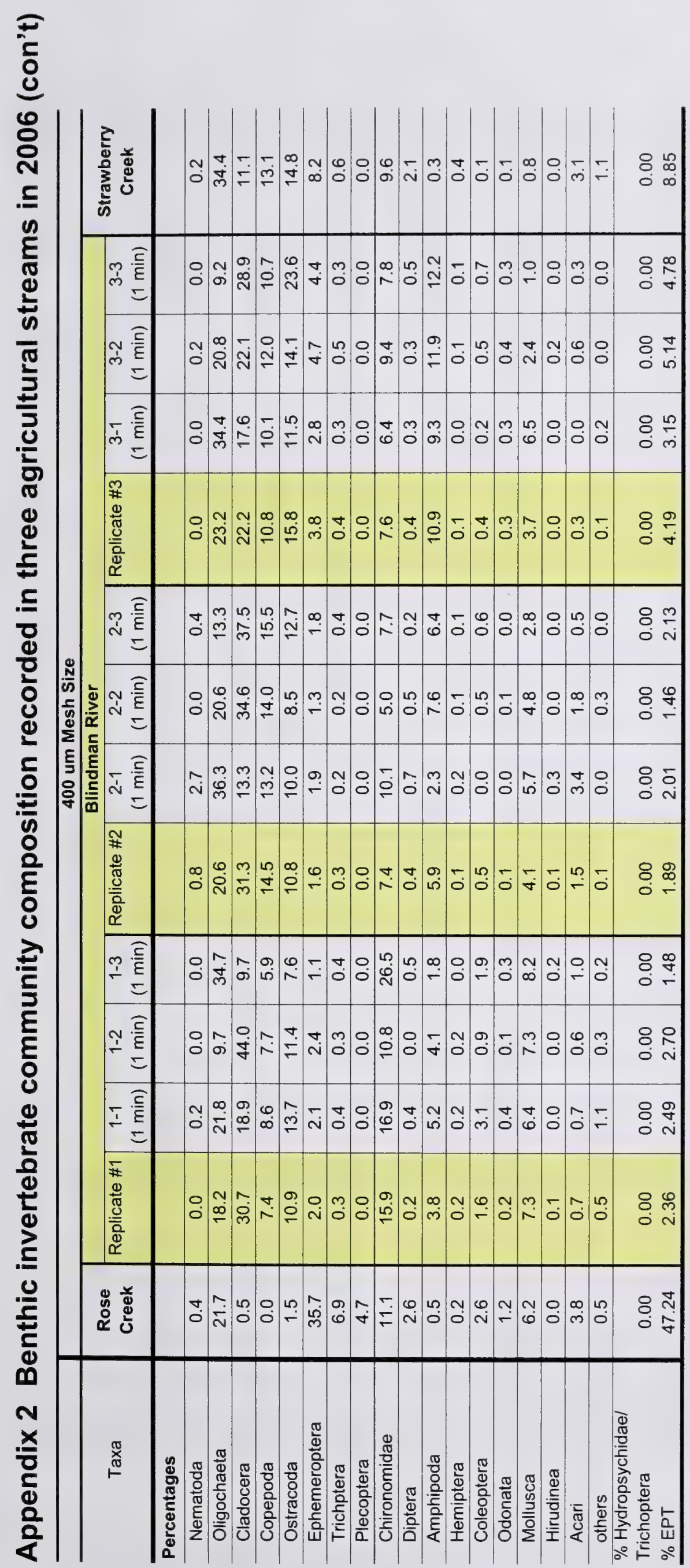




\section{Appendix 3 Epilithic algal community composition recorded in three agricultural streams in 2006}

\begin{tabular}{|c|c|c|c|c|c|c|c|c|c|c|}
\hline \multirow[t]{2}{*}{$\begin{array}{l}\text { Stream Name: } \\
\text { Date Sampled: }\end{array}$} & \multicolumn{2}{|c|}{$\begin{array}{l}\text { Rose Creek } \\
30-\text { Aug-06 }\end{array}$} & \multicolumn{2}{|c|}{$\begin{array}{c}\text { Blindman R. \#1 } \\
\text { 5-Sep-06 }\end{array}$} & \multicolumn{2}{|c|}{$\begin{array}{c}\text { Blindman R. \#2 } \\
\text { 5-Sep-06 }\end{array}$} & \multicolumn{2}{|c|}{$\begin{array}{c}\text { Blindman R. \#3 } \\
\text { 5-Seo-06 }\end{array}$} & \multicolumn{2}{|c|}{$\begin{array}{c}\text { Strawberry Creek } \\
\text { 31-Aug-06 }\end{array}$} \\
\hline & Density & Biomass & Density & Biomass & Density & Biomass & Density & Biomass & Density & \\
\hline
\end{tabular}

Bacilarriophyceae (Diatoms)

Achananthes delicatula (Kuetzing)

Grunow

Achnanthes lanceolata (Brebisson)

Grunow

Achnanthes minutissima Kuetzing

Amphora lybica Ehrenberg

Amphora pediculus (Kuetzing) Grunow

Amphipleura pellucida Kuetzing

Caloneis bacillum (Grunow) Cleve

Caloneis sp

Cocconeis pediculus Ehrenberg

Cocconeis placentula var lineata

(Ehrenberg) Van Heurck

Craticula halophila (Grunow et Van Heurck)

D. G. Mann

Cyclotella meneghiniana Kuetzing

Cyclotella ocellata Pantocsek

Cymbella microcephala Grunow

Cymbella minuta Hilse

Cymbella perpusilla Cleve Euler

Cymbella silesiaca Bleisch ex.

Rabenhorst

Cymbella sinuata Gregory

Denticula kuetzingii Grunow

Denticula subtilis Grunow

Diatoma moniliformis Kuetzing

Diatoma tenuis Agardh

Diatoma vulgaris Bory

Didymosphaeria geminata (Lyngyb.) M.

Schmidt

Diploneis puella (Schumann) Cleve

Epithemia adnata (Kuetzing)

Brebisson

Epithemia sorex Kuetzing

Fragilaria vaucheriae (Kuetzing)

Petersen

Gomphonema acuminatum Ehrenberg

Gomphonema augur var sphaeophorum

(Ehrenberg) Lange-Bertalot

Gomphonema olivaceum (Hornemann)

Brebisson

Gomphonema parvulum Kuetzing

Gomphonema pumilum (Grunow) Reichardt

\& Lange-Bertalot

Gomphonema sp

Hantzschia amphioxys (Ehrenberg)

Grunow

Mastogloia smithii Thwaites ex. W. Smith

Melosira varians (Agardh)

Navicula lanceolata (Agardh) Ehrenberg

Navicula agrestis Hustedt

Navicula bryophila Petersen

Naviucula capitatoradiata Germain

Navicula cincta (Ehrenberg) Ralfs

Navicula cryptocephala Kuetzing

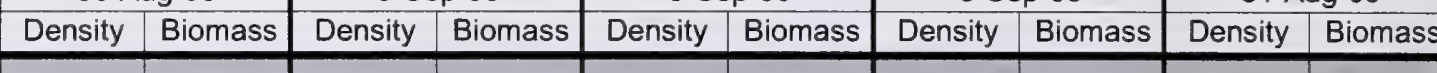

\begin{tabular}{rr|r|r|r|r|r|r|r|r}
\hline 0 & 0 & 9884 & 3.203 & 3503 & 0.694 & 4170 & 1.52 & 1786 & 0.394 \\
\hline 5530 & 0.553 & 34596 & 3.243 & 17517 & 1.752 & 20854 & 2.085 & 7147 & 0.715 \\
\hline
\end{tabular}

\begin{tabular}{r|r|r|r|r|r|r|r|r|r|}
\hline 29496 & 0.995 & 98848 & 5.931 & 36202 & 1.14 & 46921 & 2.628 & 477070 & 16.101 \\
\hline
\end{tabular}

\begin{tabular}{r|r|r|r|r|r|r|r|r|r}
0 & 0 & 0 & 0 & 2335 & 0.2 & 3128 & 0.205 & 0 & 0 \\
\hline 11061 & 0.18 & 29654 & 0.483 & 2335 & 0.041 & 8341 & 0.116 & 0 & 0
\end{tabular}

\begin{tabular}{|r|r|r|r|r|r|r|r|r|r|r|r|r|r|r|r|r|}
\hline 1843 & 2.301 & 9884 & 8.224 & 2335 & 2.616 & 0 & 0 & 17867 & 18.861 \\
\hline
\end{tabular}

\begin{tabular}{|r|r|r|r|r|r|r|r|r|r|}
7374 & 0.83 & 9884 & 0.68 & 0 & 0 & 0 & 0 & 21441 & 2.144 \\
\hline 0 & 0 & 0 & 0 & 0 & 0 & 0 & 0 & 1786 & 0.335 \\
\hline
\end{tabular}

\begin{tabular}{r|r|r|r|r|r|r|r|r|r}
36870 & 117.883 & 9884 & 58.123 & 9342 & 54.935 & 5213 & 30.656 & 0 & 0 \\
\hline
\end{tabular}

$55 \quad 130.774$

-

.

5

5530

129045

129045

\begin{tabular}{rr|r|r|r|r|}
\hline & 130.774 & 242178 & 102.926 & 162328 & 73.048 \\
\hline 0 & 0 & 0 & 0 & 0 & 0 \\
\hline 0 & 0 & 9884 & 15.9 & 2335 & 0.917 \\
\hline 0 & 0 & 2471 & 0.97 & 0 & 0 \\
\hline
\end{tabular}

\begin{tabular}{|r|r|r|r|r|r|}
\hline 0 & 0 & 2471 & 0.97 & 0 & 0 \\
\hline 0 & 0.394 & 0 & 0 & 1167 & 0.032 \\
\hline & & 0 & 0 & 0 & 0 \\
\hline
\end{tabular}

0

0.293

\begin{tabular}{ll|l|l|l|l|l|}
0 & 0 & 0 \\
0 & 0 & 0
\end{tabular}

\begin{tabular}{|r|r|r|r|}
0 & 0 & 0 & 0 \\
\hline 0 & 0 & 0 & 0 \\
\hline 05 & 15.324 & 0 & 0 \\
\hline
\end{tabular}

\begin{tabular}{|r|r|r|}
\hline 0 & 0 & 0 \\
\hline 0 & 0 & 0
\end{tabular}

97705

141949

14748
0

\begin{tabular}{r|r|r|r|r|}
\hline 08 & 1.062 & 0 & 0 \\
\hline 0 & 0 & 0 & 0 \\
\hline & 0 & 0 & 0 \\
\hline
\end{tabular}

\begin{tabular}{|c|c|c|c|c|c|c|c|c|c|}
\hline 0 & 0 & 0 & 0 & 1167 & 1.737 & 0 & 0 & 0 & 0 \\
\hline 14748 & 6.4 & 32125 & 29.046 & 15181 & 10.295 & 9384 & 5.154 & 0 & 0 \\
\hline 0 & 0 & 7413 & 1.207 & 4671 & 0.95 & 5213 & 1.508 & 0 & 0 \\
\hline 5530 & 0.625 & 0 & 0 & 2335 & 0.264 & 0 & 0 & 0 & 0 \\
\hline 0 & 0 & 4942 & 0.559 & 0 & 0 & 0 & 0 & 0 & 0 \\
\hline 0 & 0 & 0 & 0 & 0 & 0 & 0 & 0 & 1786 & 0.858 \\
\hline 0 & 0 & 0 & 0 & 2335 & 0.934 & 0 & 0 & 112567 & 92.868 \\
\hline 3687 & 7.819 & 0 & 0 & 0 & 0 & 0 & 0 & 0 & 0 \\
\hline 0 & 0 & 0 & 0 & 1167 & 1.46 & 0 & 0 & 0 & 0 \\
\hline 0 & 0 & 27183 & 1.305 & 1167 & 0.065 & 0 & 0 & 0 & 0 \\
\hline 0 & 0 & 7413 & 0.741 & 0 & 0 & 0 & 0 & 0 & 0 \\
\hline 14748 & 8.967 & 2471 & 1.463 & 12846 & 8.222 & 3128 & 2.407 & 7147 & 4.345 \\
\hline 0 & 0 & 0 & 0 & 0 & 0 & 0 & 0 & 0 & 0 \\
\hline 3687 & 2.124 & 22240 & 11.743 & 29195 & 10.729 & 11469 & 5.873 & 1786 & 0.7 \\
\hline
\end{tabular}

\begin{tabular}{|r|r|r|r|r|r|r|r|r|r}
14748 & 6.4 & 32125 & 29.046 & 15181 & 10.295 & 9384 & 5.154 & 0 & 0 \\
\hline 0 & 0 & 7413 & 1.207 & 4671 & 0.95 & 5213 & 1.508 & 0 & 0 \\
\hline 5530 & 0.625 & 0 & 0 & 2335 & 0.264 & 0 & 0 & 0 & 0 \\
\hline 0 & 0 & 4942 & 0.559 & 0 & 0 & 0 & 0 & 0 & 0 \\
\hline 0 & & & & & & & & & \\
\hline 0 & 0 & 0 & 0 & 0 & 0 & 0 & 0 & 1786 & 0.858 \\
\hline 3687 & 7.819 & 0 & 0 & 2335 & 0.934 & 0 & 0 & 112567 & 92.868 \\
\hline 0 & 0 & 0 & 0 & 1167 & 1.46 & 0 & 0 & 0 & 0 \\
\hline 0 & 0 & 27183 & 1.305 & 1167 & 0.065 & 0 & 0 & 0 & 0 \\
\hline 0 & 0 & 7413 & 0.741 & 0 & 0 & 0 & 0 & 0 & 0 \\
\hline 14748 & 8.967 & 2471 & 1.463 & 12846 & 8.222 & 3128 & 2.407 & 7147 & 4.345 \\
\hline 0 & 0 & 0 & 0 & 0 & 0 & 0 & 0 & 0 & 0 \\
\hline 3687 & 2.124 & 22240 & 11.743 & 29195 & 10.729 & 11469 & 5.873 & 1786 & 0.7 \\
\hline
\end{tabular}




\section{Appendix 3 Epilithic algal community composition recorded in three agricultural streams in 2006 (con't)}

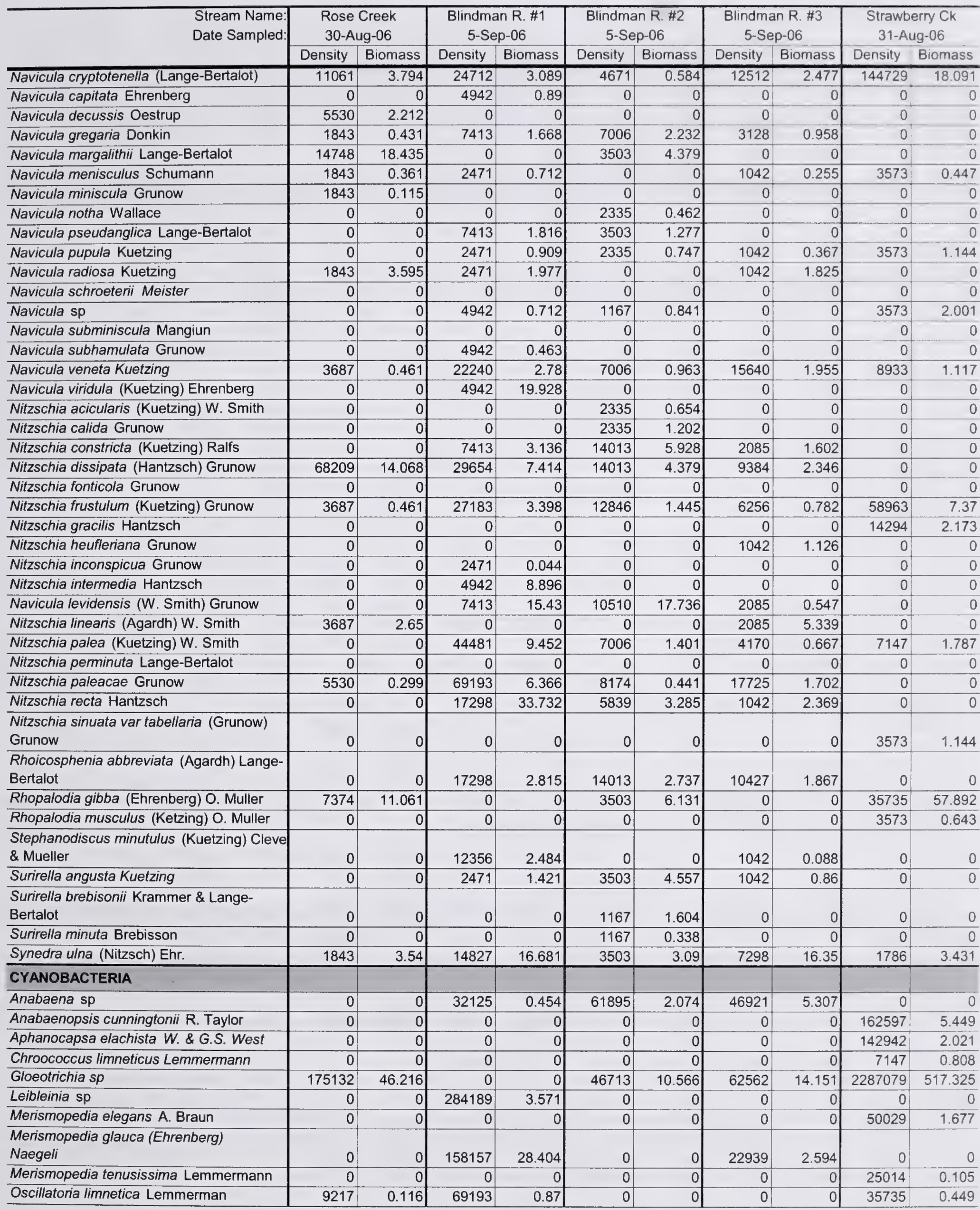




\section{Appendix 3 Epilithic algal community composition recorded in three agricultural streams in 2006}

\begin{tabular}{|c|c|c|c|c|c|c|c|c|c|c|}
\hline $\begin{array}{l}\text { Stream Name: } \\
\text { Date Sampled: }\end{array}$ & \multicolumn{2}{|c|}{$\begin{array}{c}\text { Rose Creek } \\
\text { 30-Aug-06 }\end{array}$} & \multicolumn{2}{|c|}{$\begin{array}{l}\text { Blindman R. \#1 } \\
\text { 5-Sep-06 }\end{array}$} & \multicolumn{2}{|c|}{$\begin{array}{l}\text { Blindman R. \#2 } \\
\text { 5-Sep-06 }\end{array}$} & \multicolumn{2}{|c|}{$\begin{array}{l}\text { Blindman R. \#3 } \\
\text { 5-Sep-06 }\end{array}$} & \multicolumn{2}{|c|}{$\begin{array}{l}\text { Strawberry Ck } \\
\text { 31-Aug-06 }\end{array}$} \\
\hline Phormidium sp1 & 110610 & 8.34 & 331142 & 24.968 & 159992 & 16.084 & 132423 & 13.313 & 62537 & 6.287 \\
\hline Planktolyngya limnetica Lemmermann & 0 & 0 & 0 & 0 & 0 & 0 & 0 & 0 & 1786 & 0.022 \\
\hline Pseudanabaena limnetica Komarek & 0 & 0 & 0 & 0 & 0 & 0 & 0 & 0 & 0 & 0 \\
\hline Tolypothrix sp & 36870 & 14.826 & 197697 & 105.998 & 23356 & 7.191 & 93843 & 28.892 & 955927 & 216.226 \\
\hline Ankistrodesmus gracilis (Reinsch) Kors. & 0 & 0 & 0 & 0 & 0 & 0 & 1042 & 0.049 & 0 & 0 \\
\hline $\begin{array}{l}\text { Ankistrodesmus spiralis (Turner) } \\
\text { Lemmermann }\end{array}$ & 0 & 0 & 0 & 0 & 0 & 0 & 0 & 0 & 3573 & 50.52 \\
\hline Cladophora sp & 0 & 0 & 0 & 0 & 4671 & 15.849 & 0 & 0 & 76831 & 486.609 \\
\hline Cosmarium granatum Brebisson & 0 & 0 & 0 & 0 & 0 & 0 & 0 & 0 & 3573 & 28.98 \\
\hline $\begin{array}{l}\text { Monoraphidium contortum (Thuret) } \\
\text { Komarkova-Legenerova }\end{array}$ & 0 & 0 & 0 & 0 & 2335 & 0.077 & 0 & 0 & 0 & 0 \\
\hline $\begin{array}{l}\text { Monoraphidium griffithii (Berkeley) } \\
\text { Komarkova-Legenerova }\end{array}$ & 1843 & 0.232 & 0 & 0 & 0 & 0 & 0 & 0 & 21441 & 0.909 \\
\hline $\begin{array}{l}\text { Monoraphidium minutum (Nag.) } \\
\text { Komarkova-Legenerova }\end{array}$ & 0 & 0 & 0 & 0 & 0 & 0 & 0 & 0 & 0 & 0 \\
\hline $\begin{array}{l}\text { Monoraphidium pusillum (Printz) Kom- } \\
\text { Legn. }\end{array}$ & 0 & 0 & 0 & 0 & 0 & 0 & 0 & 0 & 0 & 0 \\
\hline Mougeotia sp. & 0 & 0 & 0 & 0 & 0 & 0 & 0 & 0 & 17867 & 37.82 \\
\hline Oocystis solitaria Wittrock & 0 & 0 & 0 & 0 & 0 & 0 & 0 & 0 & 0 & 0 \\
\hline Pediastrum boryanum (Turpin) Meneghini & 0 & 0 & 0 & 0 & 0 & 0 & 0 & 0 & 7147 & 318.778 \\
\hline Pediastrum tetras (Ehrenberg) Ralfs & 0 & 0 & 0 & 0 & 0 & 0 & 0 & 0 & 0 & 0 \\
\hline Scenedesmus sempervirens Chodat & 0 & 0 & 0 & 0 & 0 & 0 & 0 & 0 & 0 & 0 \\
\hline Scenedesmus sp & 0 & 0 & 0 & 0 & 0 & 0 & 0 & 0 & 0 & 0 \\
\hline Spirogyra sp Link & 0 & 0 & 0 & 0 & 4671 & 126.795 & 0 & 0 & 0 & 0 \\
\hline Stigeoclonium sp & 0 & 0 & 0 & 0 & 0 & 0 & 0 & 0 & 0 & 0 \\
\hline Tatraedron caudatum (Corda) Hansgirg & 0 & 0 & 0 & 0 & 0 & 0 & 0 & 0 & 1786 & 0.936 \\
\hline XANTHOPHYCEAE & & & & & & & & & & \\
\hline Characiopsis sp & 0 & 0 & 0 & 0 & 2335 & 0.235 & 0 & 0 & 0 & 0 \\
\hline DINOPHYCEAE & & & & & & & & & & \\
\hline $\begin{array}{l}\text { Gymnodinium pusillum (Penard) } \\
\text { Lemmermann }\end{array}$ & 0 & 0 & 0 & 0 & 0 & 0 & 0 & 0 & 1786 & 8.981 \\
\hline
\end{tabular}




\section{Appendix 4 Phytoplankton density (number of units/L) and biomass (milligram/m3) in agricultural streams (2006)}

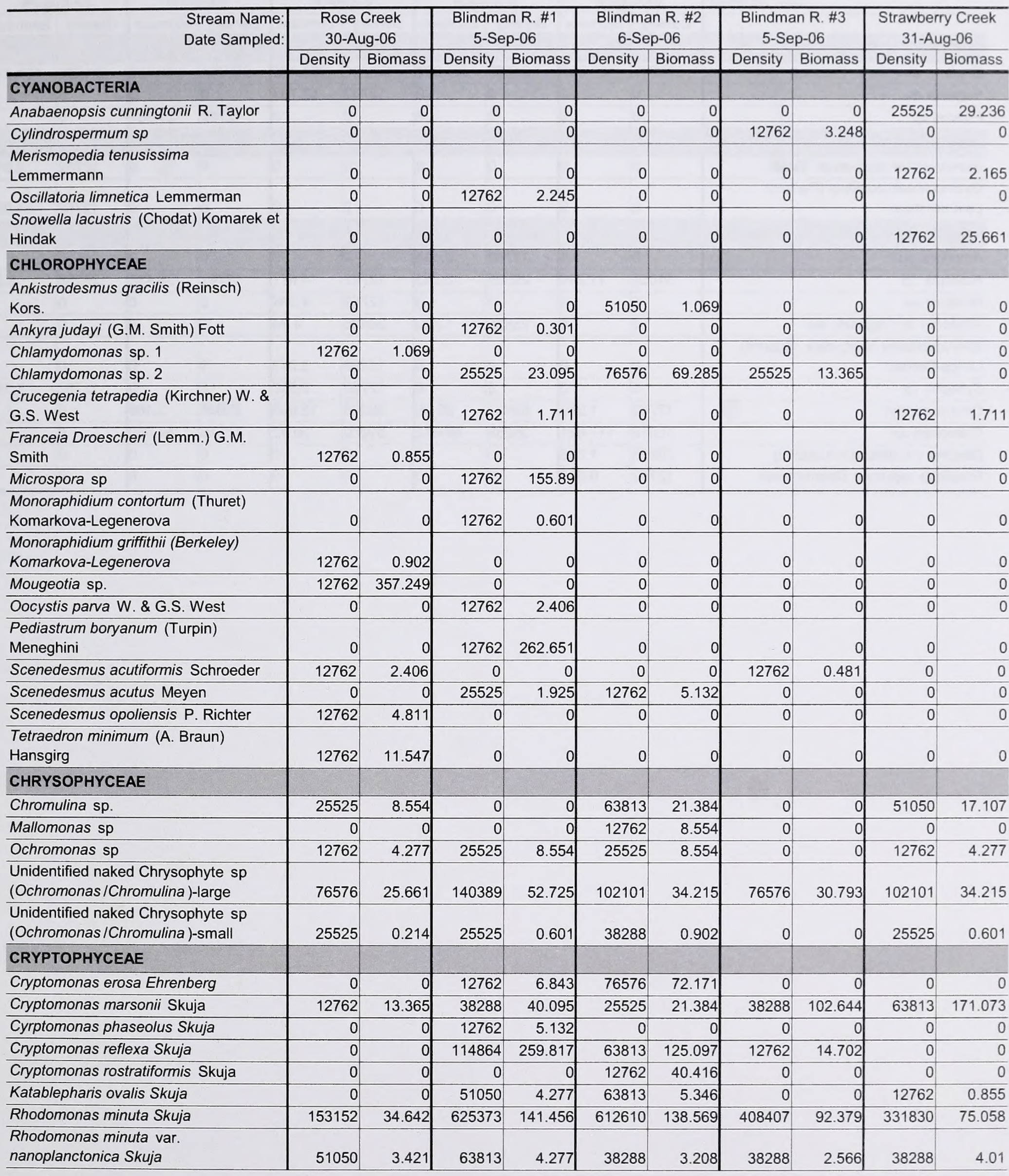




\section{Appendix 4 Phytoplankton density (number of units/L) and biomass (milligram/m3) in agricultural streams (2006)}

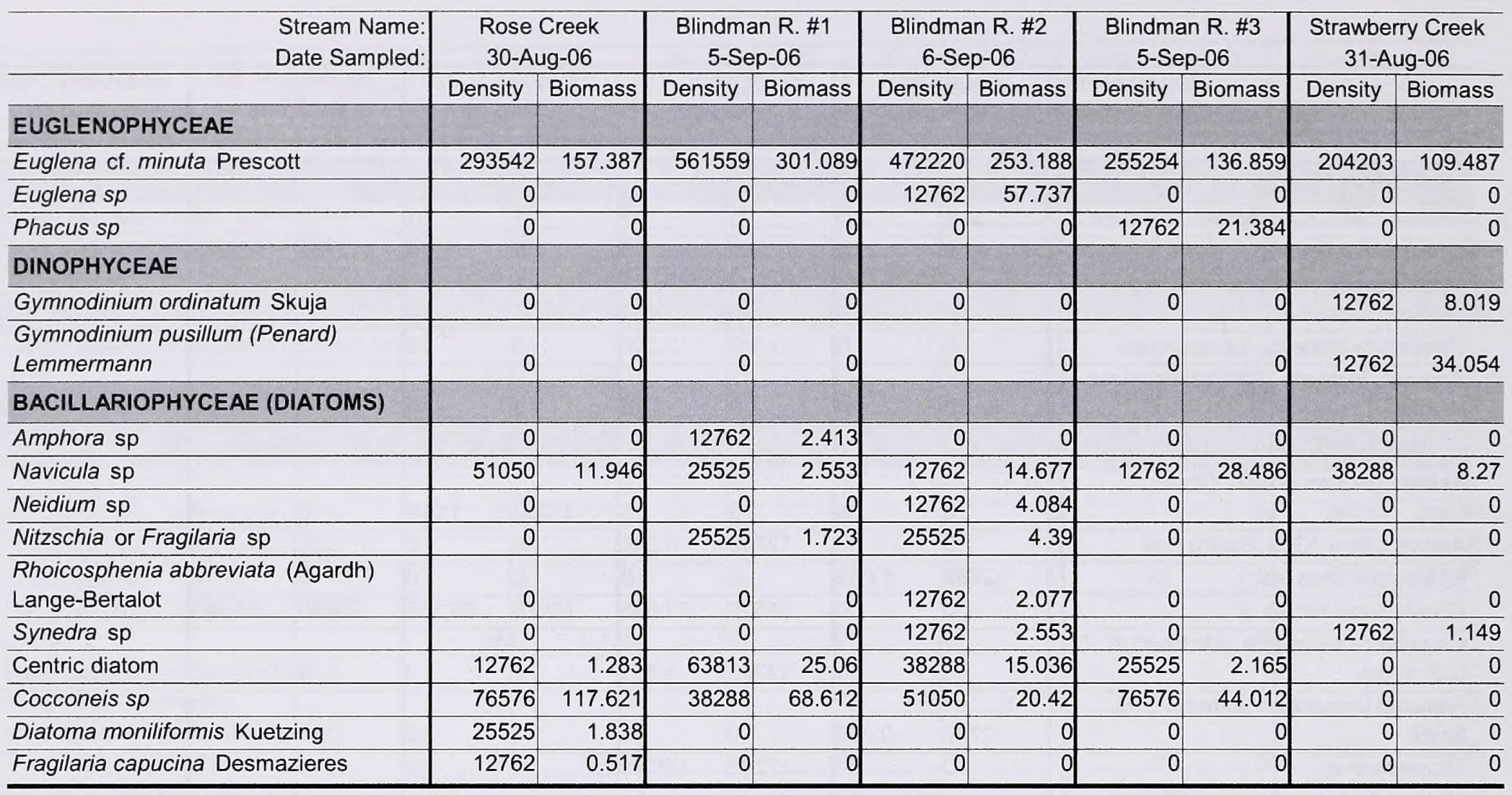




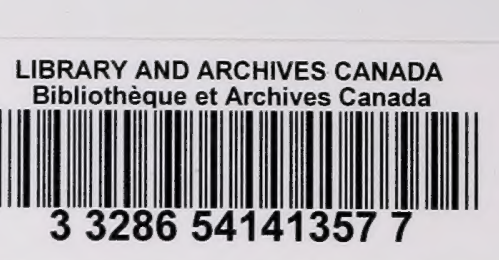

